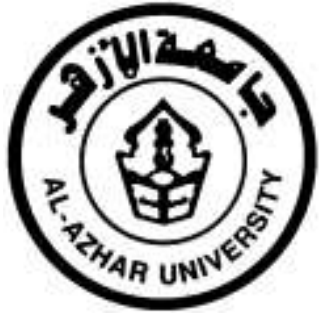

$$
\begin{aligned}
& \text { جامعــت الأزهــــر } \\
& \text { كليـت أصــول الديـن } \\
& \text { واللدعوة الإسلاميت بالمنوفيت }
\end{aligned}
$$

\title{
إقاهة الحجة
}

على مدعى ثلهين القراء السبعة

\section{إعاو الركتور}

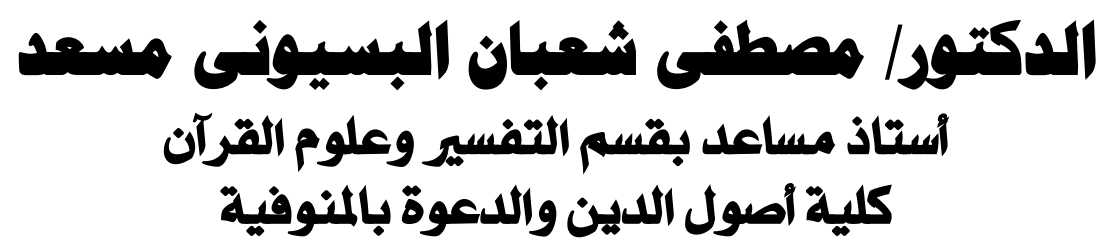

os äliwo

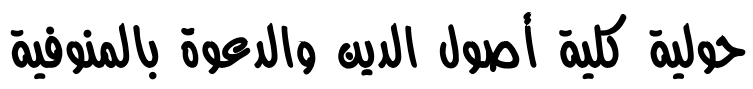

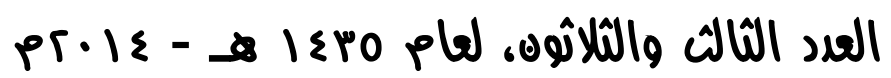

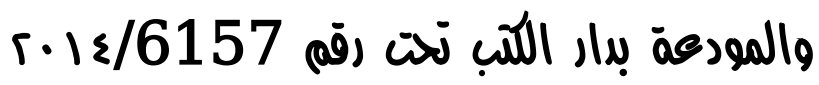

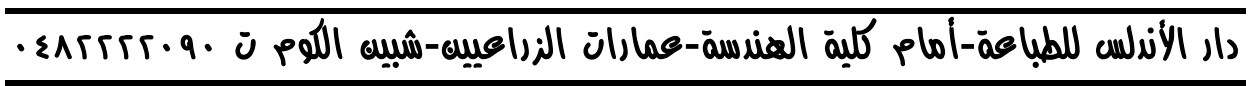




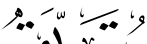

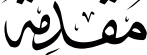

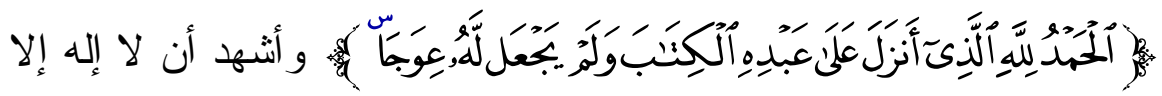

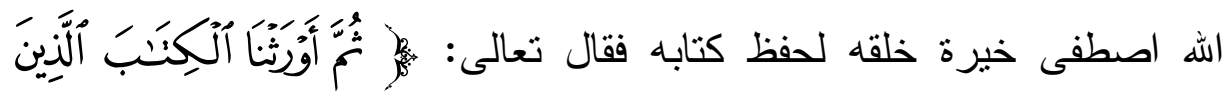

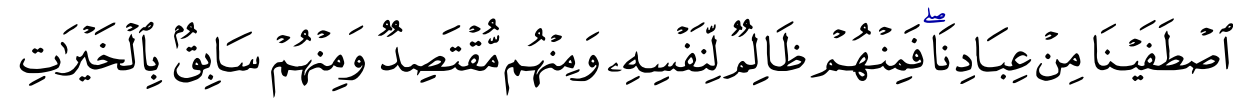

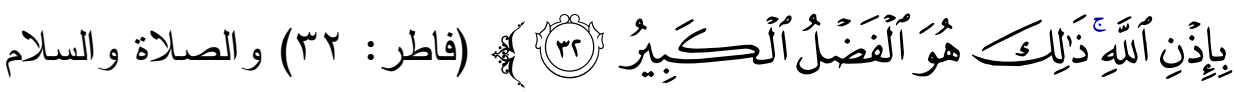
الأتمان الأكملان على من كان خلقه القرآن ووصيته القرآن وميراثه القرآن القائل فى حديثه الثريف المروي عن ذى النورين عن أثرف الخلق أجمعين "خيركم من تعلم القر آن و علمه"(')

\section{وبعد6666،}

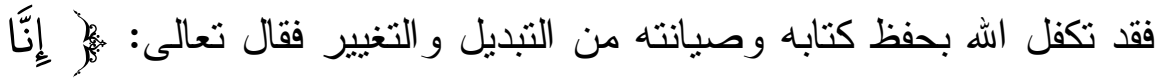

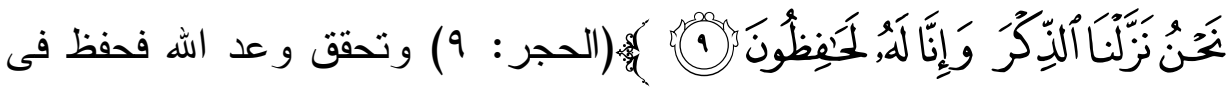

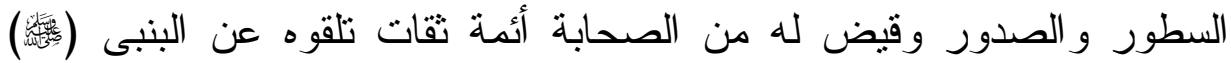
وحفظوه بقلوبهم وو عوه فى صدور هم بجميع قر اءاته ورو اته ثم جاء من بعدهم

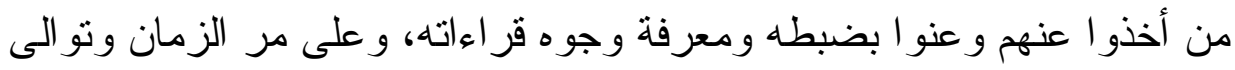
الأيام تفرقوا فى الأمصار و اثتهر أمرهم وذاع صيتهم فصاروا قبلة يقصدها

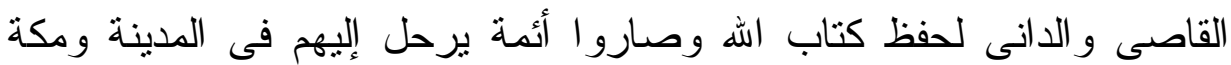
و الكوفة و البصرة والثام ومصر وكثر الآخذون عنهم وخلفهم خلق كثير عرفت

(1) صحيح البخارى كتاب فضائل القر آن باب خيركم من تعلم القــــ آن جع ص • ب 9 اط دار

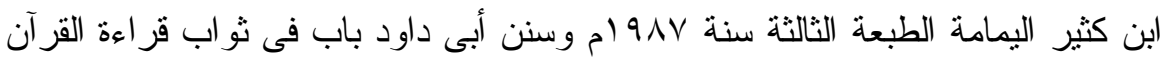

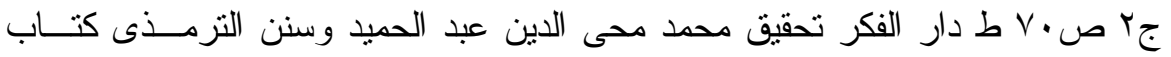

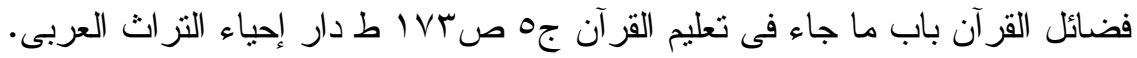
$-r-$ 
طبقاتهم واختلفت صفاتهم فكان منهم المتقن المشهور بالتاوة ومنهم المقتصر على وصف من هذه الصفات وكثز بينهم الاختلاف وقل الضبط و اتسع الخرق

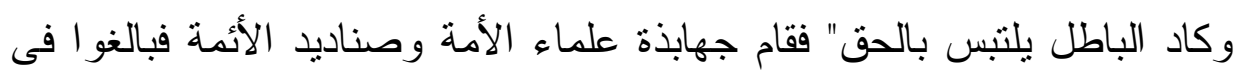
الاجتهاد وبلغوا الحق المر اد وجمعوا الحروف و القراءات وميزوا بين المشهور و الثاذ و الصحيح بأصول أصلو ها وأركان فصلوها وبسبب تصدى هؤلاء الأعلام لتلقى القراءات و إقر ائها نسبت إليهم فهى نسبة تمبيز فقط لا ونسبة انشاء"(') وما أخذ عنهم من قراعات سبيلها الأوحد هو السماع والروآية:

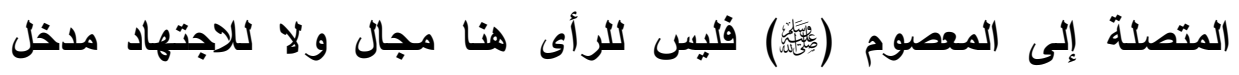
فالقر اعة سنة متبعة ولكن جاء من بعدهم من نسب إلي بعضهم اللحن و الخطأ و

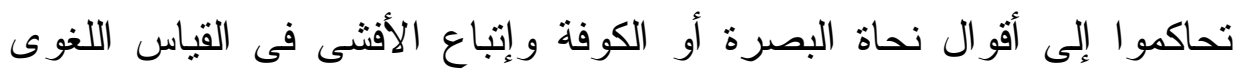
ونسو أو تتاسو أن الحكم على القراءة بالصحة أو الضعف يرجع فى أساسه إلى الروآية: وصحة النقل، فإذا ثتبت القراعة وصح نقلها وجب إنباعها لأنها سنة منبعة لابد من التز امها و المصير إليها ولو خالفت الأقيسة اللغوية والقو اعد

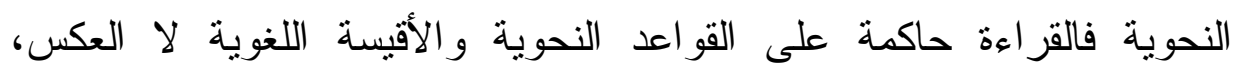
وجاءت هذه الدر اسة التى بين أيدينا تتلمس خطى أهل النقل و الروآية: و العلم و الدر آية: فى دفع التهمة و الريب وسوء الظن بأئعة القر اءات الثقات أهل الضبط الته و الإتقان فى هذا الثأن والاحتجاج لهم بصحة النقل والروآية: وموافقة لغات العرب، وقصرتها على السبعة المجمع على تواتر قراءاتهم، وسميتها إقامة الحجة على مدعى تلحين القر اء السبعة وقسمتها إلى ولى

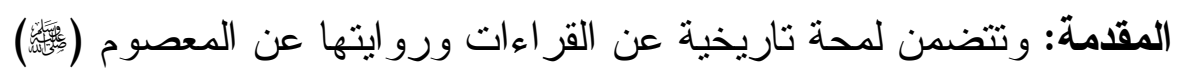

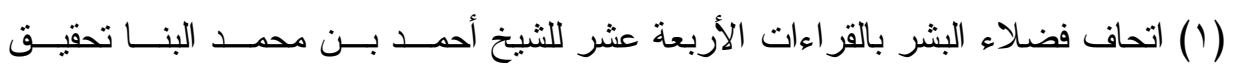

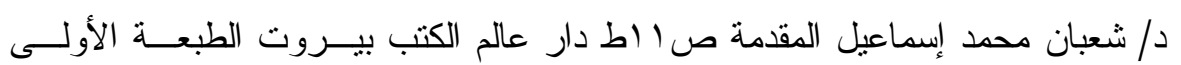


الفصل الأول: ترجمة أئمة القر اءات السبع وحكمها من حيث القبول و الرد. الفصل الثانى: القر اءات التى نسب إليها اللحن ودفعه. الخاتمة: و تتضمن نتيجة الدر اسة و البحث و اتبعت فى هذه الدر اسة الخطو ات المنهجية التالية:

$$
\text { أ- قمت بعزو الآيات إلى سور ها. }
$$

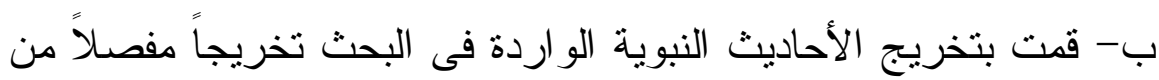
أمهات الكتب الحديثية المعتبرة لاى علماء التخريج فذكرت اسم المصدر و الكتاب و الباب ورقم الجزء و الصفحة و اسم الطبعة.

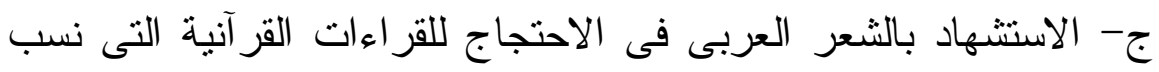
إلبها اللحن، وعزوت الأبيات الثعرية إلى قائليها وذكرت الديوان ورقم الصفحة

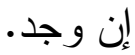

د- الترجمة لبعض الأعلام المبهمة فى هذا البحث.

هـ - ذكرت فى هذه الدر اسة أقو ال أئعة القر اءات و اللغة و التفسير و عزوت الاعت الأقو ال إلى أصحابها من مظانها مع ذكر اسم المصدر و الطبعة وسنة الطبع هوه بالهامش عند ورودها فى المرة الأولى. حتى تخرج الدر اسة بصورتها المنشودة

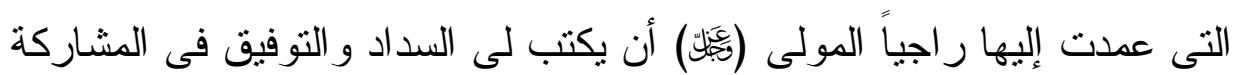
بوضع لبنة من لبنات هذا الصرح الثامخ فى علم القراءات فهو حسبى وعليه

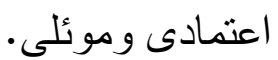

\section{راجى عفو ربه}

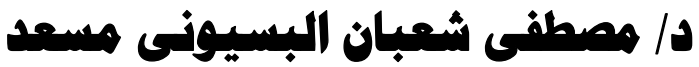

أستاذ مساعد بقسم التفسير وعلوم القرآن

كلية أصول الدين والدعوة بالمنوفية 


\section{الفصل الأول}

\section{ترجمة أنمة القراءات السبع وحكمها من حيث القبول والرده}

الوقوف على ترجمة الأئمة القراء السبعة ومعرفة صحة اتصال سندهم إلى إنى

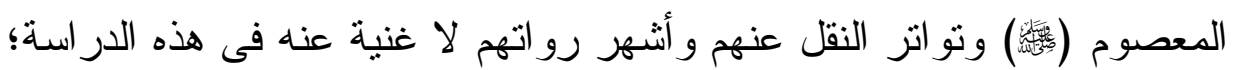
فإنه السبيل إلى معرفة كيفية دفع كثير من الثبه الواردة على هذه القراءات، فبلو غهم المكانة العظمى و الدرجة العليا فى التقة و العدالة والضبط جعلهم أئمة هذا الثأن و الأحق بالصدارة و النقل عنهم من غير هم فما أخذ عنهم من قراءات وله وعله

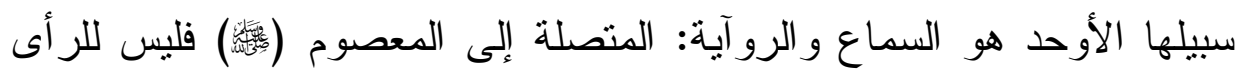
هنا مجال ولا للاجتهاد مدخل فالقر اءة سنة منبعة؛إذا علمنا هذا زالت الغناوة عن الأعين و الرين عن القلوب وسقطت الثبه لذلك آثرت أن أبدأ هذه الدراسة بالتزجمة لهم و الله الموفق.

1 - نافع المدنى: هو نافع بن عبد الرحمن بن أبي نعيم أبو رويم أحد

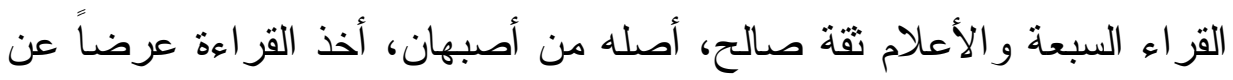
جماعة من تابعي أهل المدينة منهم عبد الرحمن بن هرمز الأعرج وأبي جعفر القارئ وشيبة بن نصاح ويزيد بن رومان ومسلم بن جندب. وقد تلقى هؤلاء

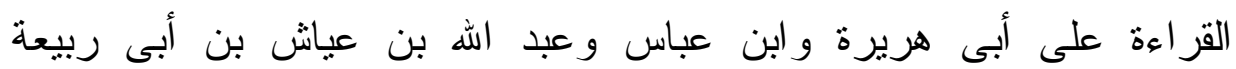

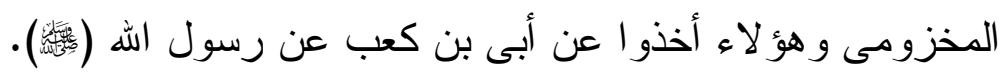
ثناء العلماء عليه: عن أحمد بن هلال قال قال لي الثيباني قال رجل مهن قر أ على نافع أن نافعاً كان إذا تكلم يشمّ من فيه ر ائحة المسك فقلت له يا أبا عبد

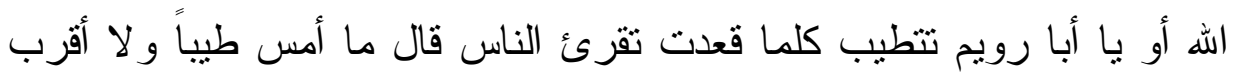

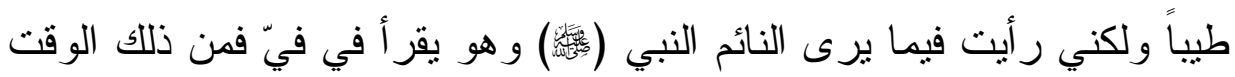
أثمّ من فيّ هذه الرائحة، وقال المسيبي قيل لنافع ما أصبح وجهك و أحسن 


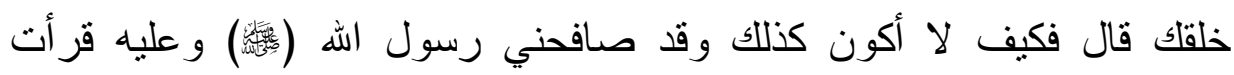
القر آن يعني في النوم، وقال قالون كان نافع من أطهر الناس خلقاً ومن أحسن

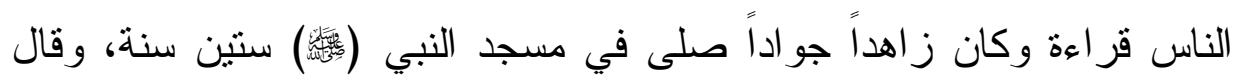
الليث بن سعد حججت سنة ثالاث عشرة ومائة و إمام الناس في القر اعة بالمدينة نافع، وقال مالك لما سئل عن البسملة سلو ا عن كل علم أهله ونافع إمام الناس في القر اءة مات سنة تسع وستين ومائة وقيل سبعين وقيل سبع وستين وقيل

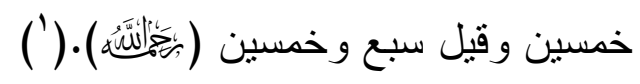
|أهدر الرواة عiه:

أ- قالون: عيسى بن مينا بن وردان بن عيسى أبو موسى الملقب قالون قارى المدينة ونحويها، سماه نافع قالون لجودة قر اعته فإن قالون بلغة الرومية جيد، وقال ابن أبي حاتم كان أصم يقرى القرآن ويفهم خطأهم ولحنهم بالثفة قال وسمعت علي بن الحسين يقول كان عيسى بن مينا قالون أصم شديد الصمح وكان يقر أ عليه القرآن وكان بنظر إلى شفتي القارى ويرد عليه اللحن و الخطأ،

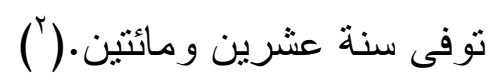

ب- ورش: عثمان بن سعيد القرشي مولاهم القبطي المصري الملقب بورش لثدة بياضه شيخ القراء المحققين و إمام أهل الأداء المرتلين انتهت إليه رئاسة الإقراء بالديار المصرية في زمانه، ولا سنة عشر ومائة بمصر، ورحل إلى نافع ابن أبي نعيم فعرض عليه القرآن عدة ختمات في سنة خمس وخمسين

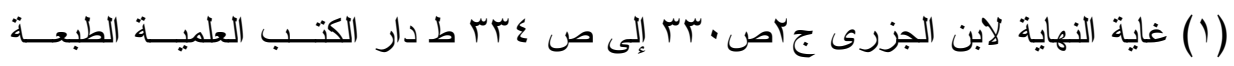

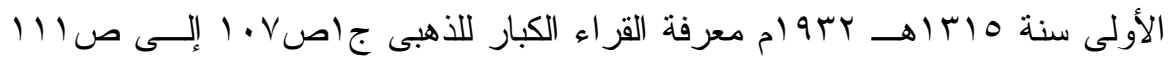
بتصرف ط مؤسسة الرسالة الطبعة الأولى سنة ؟ . أهــ.

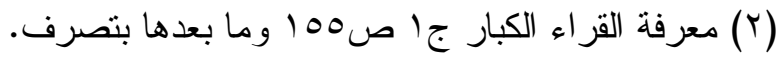


ومائة وكان جيد القزاءة حسن الصوت إذا قرأ يهمز ويمد ويشدد ويبين الإعر اب لا يمله سامعه توفي ورش بمصر سنة سبع وتسعين ومائة عن سبع

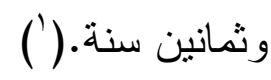

ץ- ابن كثير المكى: عبد الله بن كثير بن عمرو بن عبد الله الإمام أبو معبد المكي الداري إمام أهل مكة في القراعة، ولا بمكة سنة خمس وأربعين ولقي بها عبد الله ابن الزبير وأبا أيوب الأنصاري وأنس بن مالك ومجاهد بن

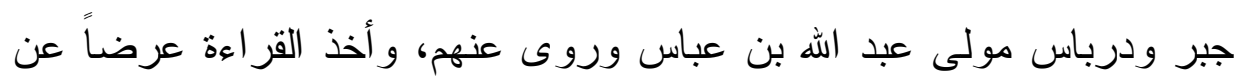

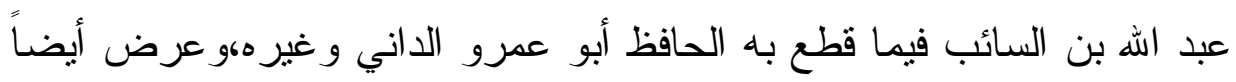
على مجاهد ابن جبر و درباس مولى عبد الله بن عباس. وقر أ ابن السائب على وعي أبى بن كعب وعمر بن الخطاب، وقر أ مجاهد على ابن السائب وعبد الله بن عباس، وقر أ درباس على ابن عباس، وقر أ ابن عباس على أبى بن كعب وزيد

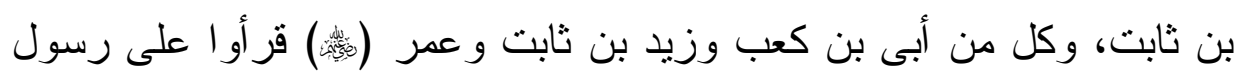

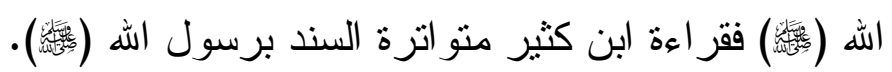
ثناء العلماء عليه: قال ابن الجزرى: كان فصيحاً بليغاً مفو ها عليه السكينة و الوقار، قال الأصمعي قلت لأبي عمرو قرأت على ابن كثير قال نعم ختمت على ابن كثير بعدما ختمت على مجاهد وكان ابن كثير أعلم بالعربية من مجاهد، قال ابن مجاهد ولم يزل عبد الله هو الإمام المجتمع عليه في القراءة بمكة حتى مات عشرين ومائة، وقال سفيان بن عيينة حضرت جنازة ابن كثير

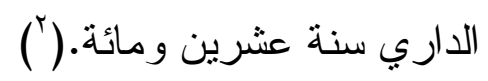

$$
\text { (1) السابق جا ص ص O ابتصرف. }
$$

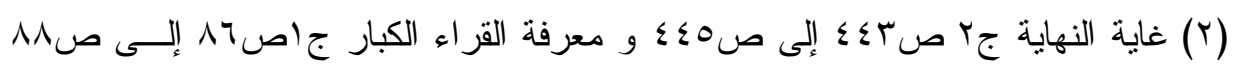

بتصرف. 


\section{|نههر الرواة عنه:}

أ- البزى: أحمد بن محمد بن عبد الله بن القاسم بن نافع بن أبي بزة مقري مكة ومؤذن المسجد الحر ام، ولد سنة سبعين ومائة أستاذ محقق ضابط مثقن.

توفي البزي سنة خمسين ومائتنين عن ثمانين سنة.(') (') ب- قتبل: محمد بن عبد الرحمن بن خالد أبو عمر المخزومي مولاهم المكي الملقب بقنبل شيخ القراء بالحجاز، ولد سنة خمس ونسعين ومائة وقد انتهت إليه رياسة الإقراء بالحجاز ورحل الناس إليه من الأقطار، مات سنة

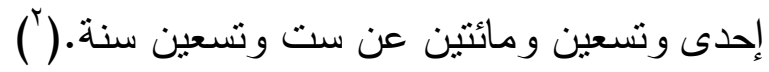
r- أبو عمرو بن العلاء البصرى: زبان بن العلاء بن عمار بن العريان الإمام السيد بن عمرو التميمي المازني البصري أحد القراء السبعة، ولا سنة ثمان وستين وقيل غير ذللك. توجه مع أبيه لما هرب من الحجاج فقر أ بمكة و المدينة وقر أ أيضاً بالكوفة و البصرة على جماعة كثيرة فليس في القر اء السبعة

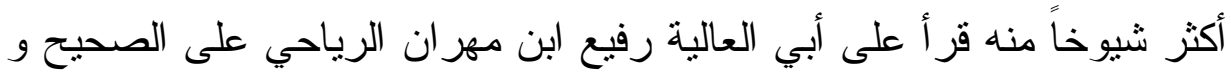
سعيد بن جبير وشيبة ابن نصاح و عاصم بن أبي النجود وعبد الله بن أبي إسحاق الحضرمي و عبد الله بن كثير المكي وعطاء بن أبي رباح ومجاهد بن جبر و أبي جعفر يزيد ابن القعقاع المدني ونافع بن أبى نعيم، وقد قر أ أبو العالية على عمر بن الخطاب و أبى بن كعب وزيد بن ثابت وعبد الله بن عباس

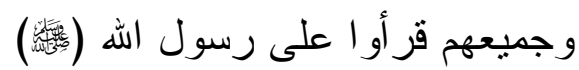

ثناء العلماء عليه: قال الأصمعي: لم أر بعد أبي عمرو أعلم منه،حدثا عبد الو ارث قال حججت سنة من السنين مع أبي عمرو بن العلاء وكان رفيقي

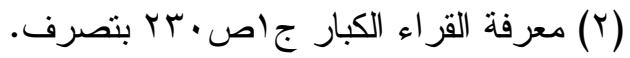


فمررنا ببعض المنازل فقال قم بنا فمشيت معه فأقعدني عند ميل وقال لي لا

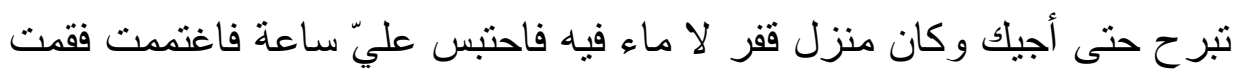

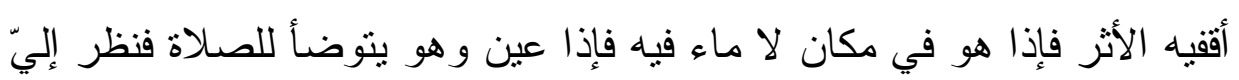

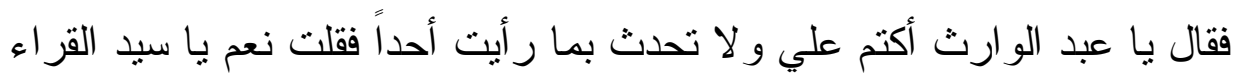

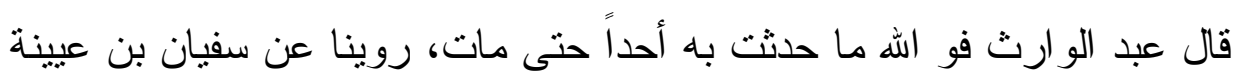

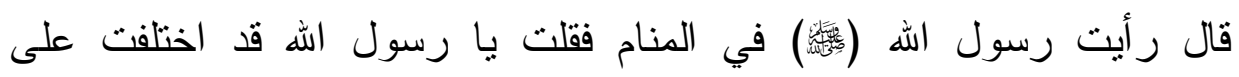

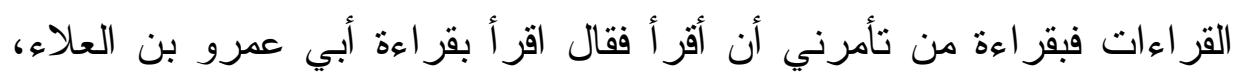

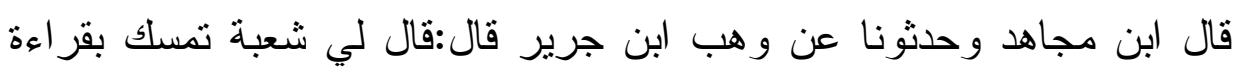

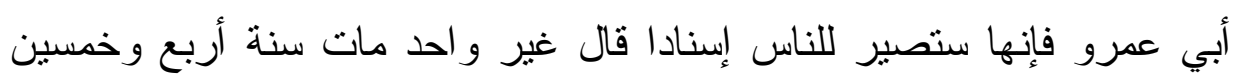

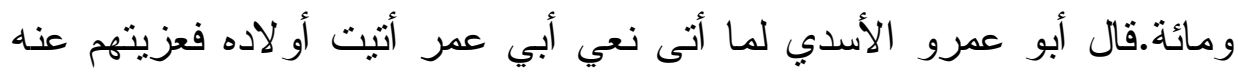

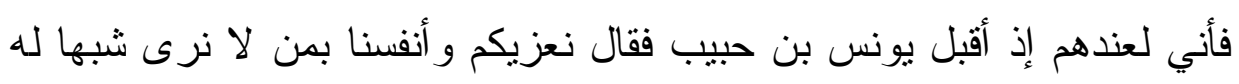

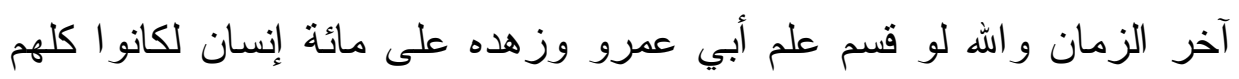

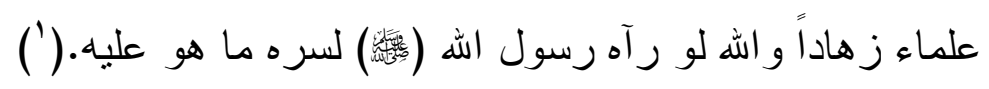

\section{| اشهر الرواة عنه:}

أ- الدورى: حفص بن عمر بن عبد العزيز بن صهبان أبو عمر الدوري

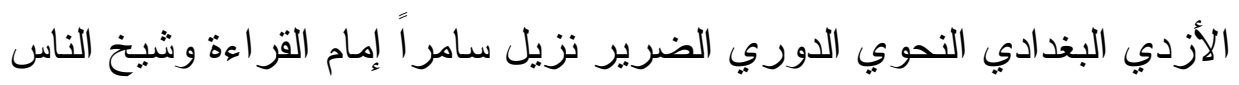

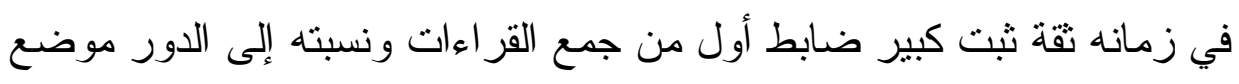

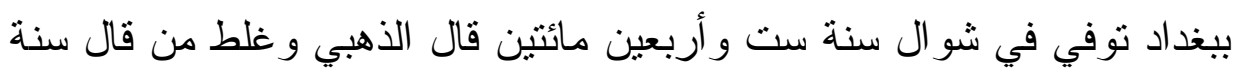

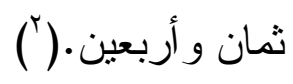

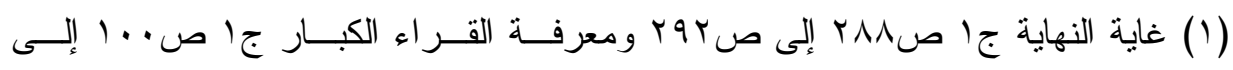
صا 1 ( بتصرف.

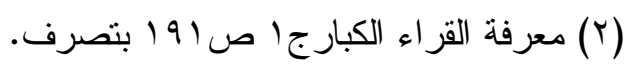


ب- السوسى: صالح بن زياد بن عبد الله بن إسماعيل بن إبراهيم أبو شعيب السوسي الرقي مقرى ضابط محرر ثقة،توفى بالرقة سنة إحدى وستين

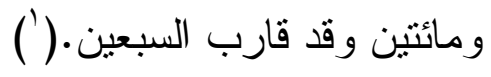

ـ - ابن عامر: هو عبد الله بن عامر بن يزيد بن تميم بن ربيعة بن عامر

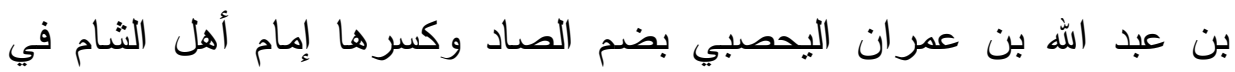

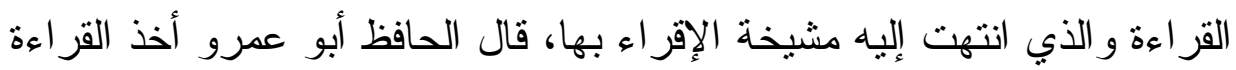

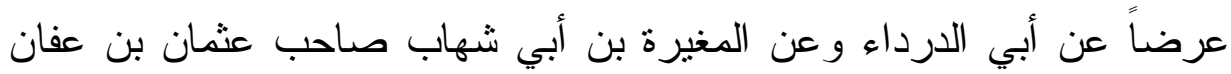
وقيل عرض على عثمان نفسه. ثناء العلماء عليه: قال ابن الجزرى: لا زال أهل الثام قاطبة على قر اءة ابن عامر تلاوة وصلاة وتلقينا إلى قريب الخمسمائة، وقال أبو علي الأهوازي إئ

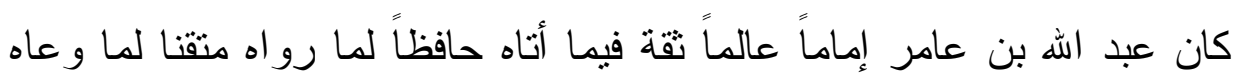
عارفاً فهما قيما فيما جاء به صادقاً فيما نقله من أفاضل المسلمين وخيار التابعين و أجلة الر اوين لا يتهم في دينه و لا يشك في يقينه و لا يرتاب في أمانته و لا يطعن عليه في روايته صحيح نقله فصيح قوله عاليا في قدره مصيباً في أمره مشهور اً في علمه مرجو عاً إلى فهمه ولم يتعد فيما ذهب إليه الأثر ولم يقل قو لا يخالف فيه الخبر ، ولي القضاء بدمشق بعد بلال بن أبي الدرداء قلت إنما

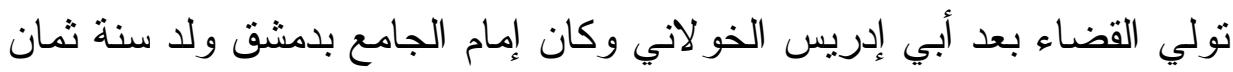
من الهجرة وقد ثبت سماعه من جماعة من الصحابة منهم معاوية بن أبي سفيان

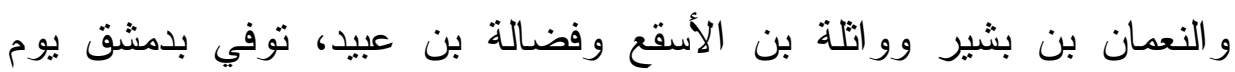

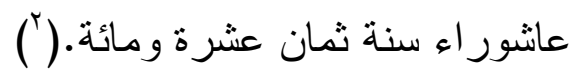

$$
\text { (1) معرفة القر اء الكبار جا صسو (19 بتصرف. }
$$

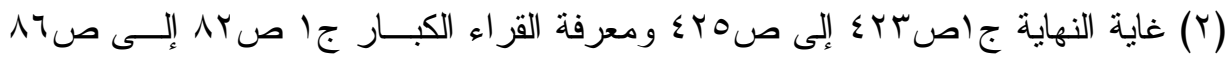
بتصرف. 


\section{أشهر الرواة عنه:}

أ- هشام: هو هشام بن عمار بن نصير بن ميسرة أبو الوليد السلمي،إمام

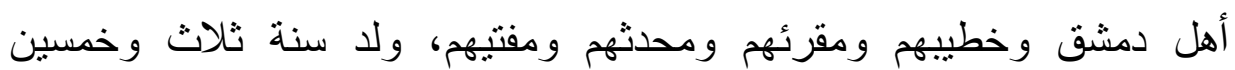

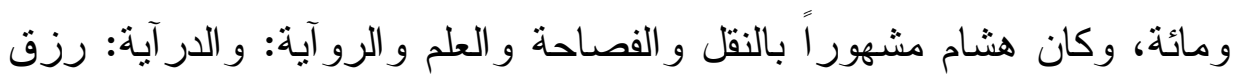

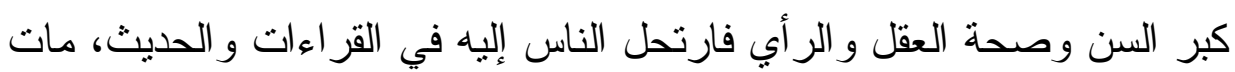

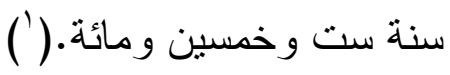
ب- ابن ذكوان: عبد الله بن أحمد بن بشر ويقال بشير بن ذكوان بن عمرو

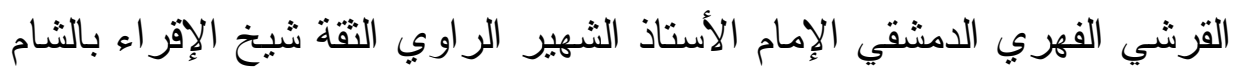

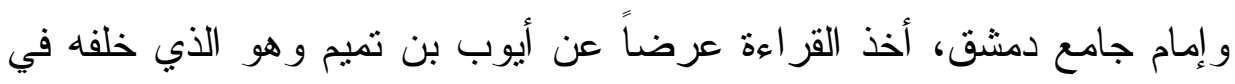

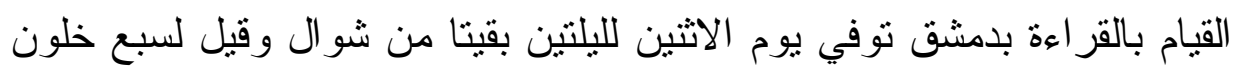

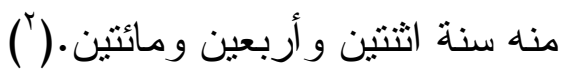

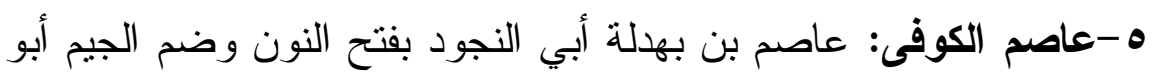

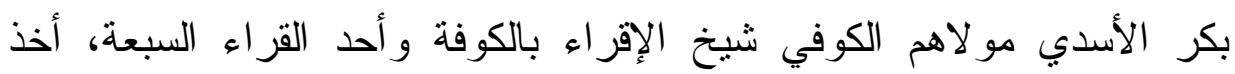

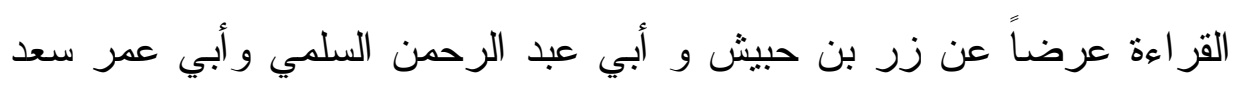

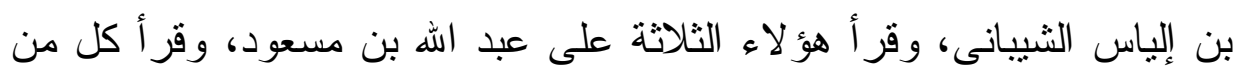

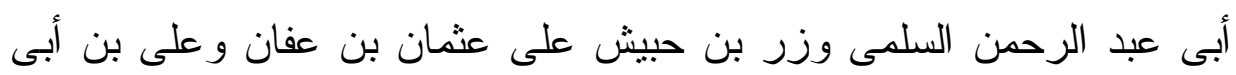

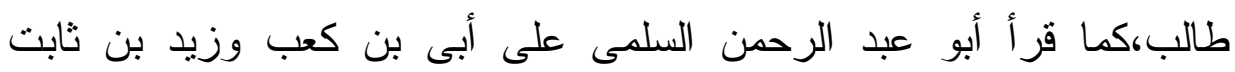

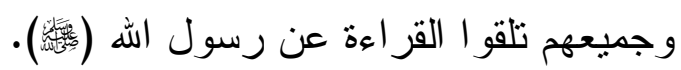

ثناء العلماء عليه: قال ابن الجزرى: هو الإمام الذي انتهت إليه رئاسة الإقراء بالكوفة بعد أبي عبد الرحمن السلمي في موضعه جمع بين الفئ الفصاحة

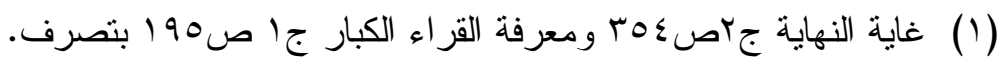

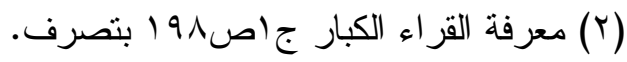


و الإتقان و التحرير و التجويد وكان أحسن الناس صوتاً بالقرآن، قال أبو بكر بن عياش لا أحصي ما سمعت أبا إسحاق السبيعي يقول ما رأيت أحداً أقر أ للقر آن بران من عاصم بن أبي النجود، وقال يحيى بن آدم ثثا حسن بن صالح قال ما رأيت أحداً قط كان أفصح من عاصم إذا تكلم كاد بدخله خيلاء، وكان من التابعين. توفي آخر سنة سبع وعثرين ومائة وقيل سنة ثمان و عشرين فلعله في أولها

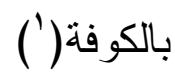

\section{|خفهر الرواة عنه:}

أ- شعبة: هو شعبة بن عياش بن سالم أبو بكر الحناط بالنون الأسدي

النهي الكوفي الإمام العلم راوي عاصم، ولا سنة خمس وتسعين من الهجرة

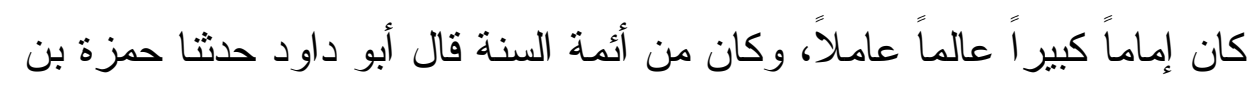
سعيد المروزي أنه ثقة توفي في جمادي الأولى سنة ثلاث وتسعين ومائة وقيل

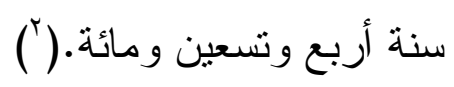

ب- حفص: هو حفص بن سليمان بن المغيرة أبو عمر بن أبي داود

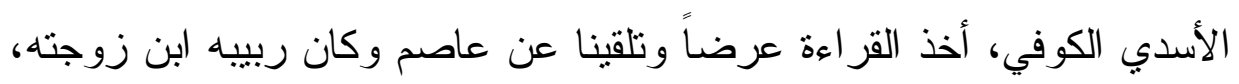
ولد سنة تسعين من الهجرة كان حفص أعلم الناس بقر اءة عاصم وقال الذهبي أما القر اءة فتقة ثبت ضابط لها بخلاف حاله في الحديث قلت يشير إلى أنه تكلم فيه من جهة الحديث توفى سنة ثمانين ومائة من الهجرة. (")

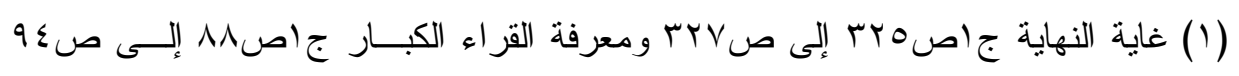
بتصرف.

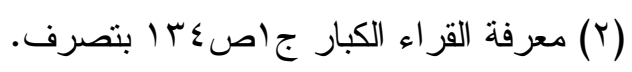

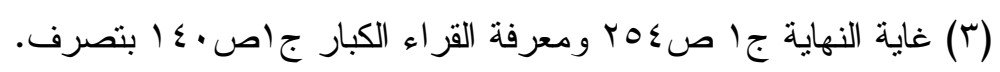


7 - حمزة الكوفى: حمزة بن حبيب بن عمارة بن إسماعيل الإمام الحبر أبو عمارة الكوفي التيمي مولاهم وقيل من صميمهم الزيات أحد القراء السبعة، ولد سنة ثمانين، أخذ القراءة عرضا عن سليمان الأعمش وحمر ان بن أعين و أبي إسحاق السبيعي ومحمد بن عبد الرحمن بن أبي ليلى وطلحة بن مصرف و

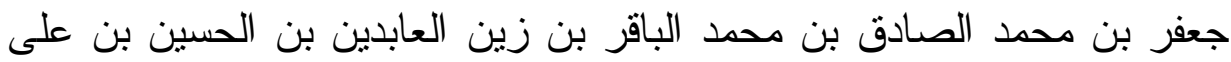
بن أبى طالب، فقر اعة حمزة ينتهى سندها إلى على بن أبى طالب و عبد الله بن

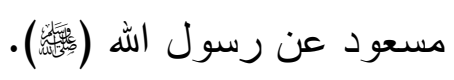
ثناء العلماء عليه: قال ابن الجزرى: صارت الإمامة في القراءة بعد عاصم و الأعمش إليه وكان إماما حجة ثقة ثبتا رضي قيما بكتاب الله بصير المال بالفر ائض عارفا بالعربية حافظا للحديث عابدا خاثعا ز اهدا ور عا قانتا له عديم النظير، قال عبد الله العجلي فال أبو حنيفة لحمزة شيئان غلبتتا عليهما لسنا ننازعك فيهما القرآن و الفرائض وقال سفيان الثوري غلب حمزة الناس على القر آن و الفر ائض وقال أيضا عنه ما قر أ حمزة حرفا من كتاب الله إلا بأثز ، ونه وكان شيخه الأعمش إذا رآه أقبل يقول هذا حبر القرآن قال يحيى بن معين سمعت محمد بن فضيل يقول ما أحسب أن الله يدفع البلاء عن أهل الكوفة إلا

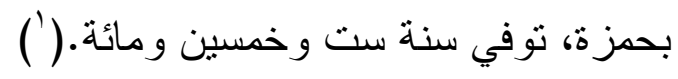

\section{أثهر الرواة عنه:}

أ- خلف: خلف بن هشام بن ثعلب أبو محمد الأسدي الإمام العلم أبو محمد

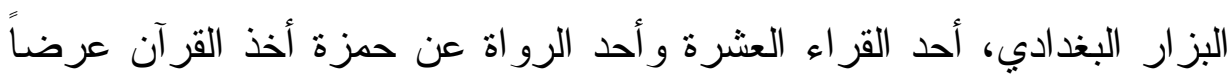
عن سليم بن عيسى وعبد الرحمن بن أبي حماد عن حمزة. ولد سنة خمسين

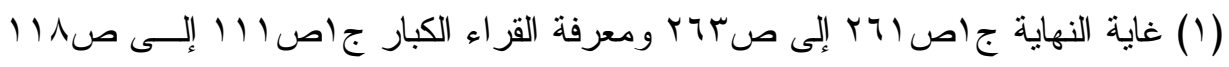
بتصرف. 
ومائة وحفظ القرآن وهو ابن عشر سنين وكان ثقة كبيراً زاهداً عابداً عالما، روينا عنه أنه قال أشكل عليَّ باب من النحو فأنفقت ثمانين ألف درهم حتى حتى حفظته مات في جمادي الآخرة سنة تسع و عشرين ومائتنن ببغداد ( ') ب- خلاد: خلاد بن خالد أبو عيسى وقيل أبو عبد الله الثيباني مولاهم الصيرفي الكوفي إمام في القراءة ثقة عارف محقق أستاذ، أخذ القراءة عرضاً عن سليم عن حمزة وهو من أضبط أصحابه وأجلهم توفي سنة عشرين ومائتين. () (r)

- الكسائى: علي بن حمزة بن عبد الله بن بهمن بن فيروز الأسدي مولاهم أبو الحسن الكسائي الإمام الذي انتهت إليه رئاسة الإقراء بالكوفة بعد

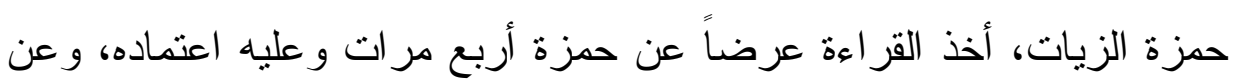
محمد بن عبد الحمن بن أبي ليلى و عيسى بن عمر الهمداني، عن أبي بكر بن

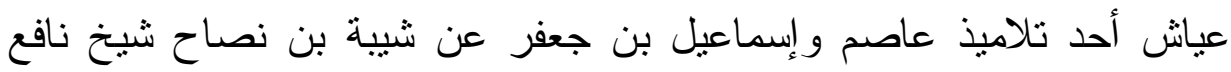

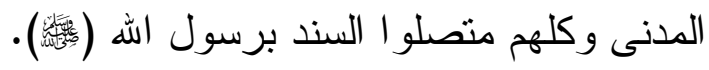
ثناء العلماء عليه: روى عنه من الأئمة الإمام أحمد بن حنبل ويحيى بن معين وقال ما رأيت بعيني هاتين أصدق لهجة من الكسائي وقال الثافعي رالي

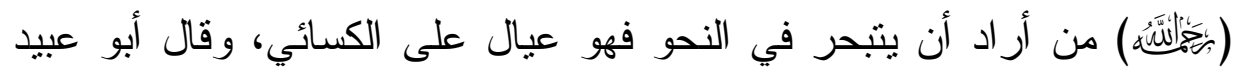
في كتاب القراءات كان الكسائي يتخير القر آت فأخذ من قر اعة حمزة ببعض أبل وترك بعضا وكان من أهل القر اعة وهي كانت علمه وصناعته ولم يجالس أحدا كان أضبط ولا أقوم بها منه، وقال ابن مجاهد فاختار من قر اعة حمزة وقر اءة غيره قر اعة متوسطة غير خارجة عن آتار من تقدم من الأئمة وكان إمام الناس

$$
\begin{aligned}
& \text { (1) معرفة القر اء الكبار ج اصدم • ب بتصرف. }
\end{aligned}
$$

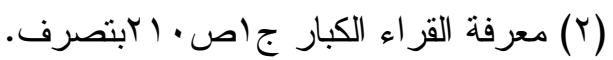


في القراءة. قال أبو بكر الأبباري اجتمعت في الكسائي أمور كان أعلم الناس بالنحو وأوحدهم في الغريب وكان أوحد الناس في القرآن فكانو ا يكثرون عليه حتى لا يضبط الأخذ عليهم فيجمعه ويجلس على كرسي ويتلو القرآن من أوله إلى آخره وهم يسمعون ويضبطون عنه حتى المقاطع و المبادي، و اختلف في تاريخ موته فالصحيح الذي أرخه غير واحد من العلماء و الحفاظ سنة تسع ونع وني

وثمانين ومائة. (')

\section{|أثهر الرواة عنه:}

أ- الليث: هو الليث بن خالد أبو الحارث البغدادي ثقة معروف حاذق ضابط، عرض على الكسائي وهو من جلة أصحابه مات سنة أربعين ومائتنين()

ب- حفص الدورى: تقدمت تزجمته فى رواة أبى عمرو بن العلاء لأنه روى عنه و عن الكسائى.

وبعد هذا العرض الوافى لترجمة هؤلاء الأئمة تبين بما لايدع مجالا للشك ثقتهم وضبطهم وعدالتهم وتواتر النقل عنهم ووجوب قبول قراعاتهم وعدم جواز الطعن عليها أو إنكار شئ منها و إليك حكم ذلك بالتفصيل. وجوب قبول القراعات المتواترة وعدم جواز الطعن عليها أو إنكار شئ منها: اتفقت الأمة - سلفها وخلفها- على تلقى القراءات السبع و الثلاث المتممة للعشر على الصحيح بالقبول و الإذعان و الحكم لها بالتواتر ، وعليه فلا يجوز

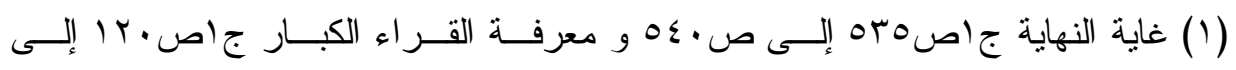

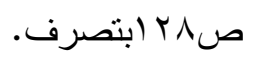

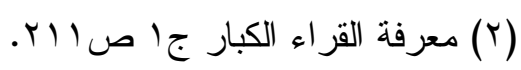


الطعن عليها أو إنكار شئ منها، فالقر اعة الثابتة بمنزلة الآية: المستقلة التى لا يجوز ردها أو رد معناها.

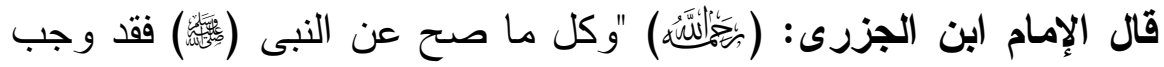
قبوله ولم يسع أحدا من الأمة رده ولزم الإيمان به وكله منزل من عند الله، إذ إذ كل قر اعة مع الأخرى بمنزلة الآية: مع الآية: يجب الإيمان بها كلها و إتباع ما تضمنته من المعنى علما وعملا و لا يجوز ترك موجب إحداهما لأجل الأخرى

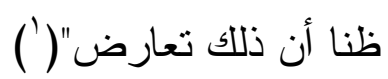

بهذا الحصن المنيع تقف القر اعة الثابتة - فضلا عن المتواترة - صامدة أمام طعن الطاعنين الذين تحاكمو إلىى أقوال نحاة البصرة أو الكوفة و إتباع الأفثى فى القياس اللغوى ونسو أو نتاسوا أن الحكم على القر اءة بالصحة أو أو الضعف يرجع فى أساسه إلى الروآية: وصحة النقل ،فإذا ثبتت القر اعة وصحح نقلها وجب إتباعها لأنها سنة متبعة لابد من التز امها و المصير إليها ولو خالفت إتها الأقيسة اللغوية والقو اعد النحوية فالقر اعة حاكمة على القو اعد النحوية والأقيسة الغوية لا العكس.

قال الإمام الاني: وأئمة القراء: لا تعمل في شيء من حروف القرآن على الإفثناء في اللغة، والأقيس في العربية بل على الأثبت في الأثر والأصح في النقل، وإذا ثبتت الروآية: لم يردها قياس عربية ولا فثنو لغة، لأن القر اءة سنة منبعة يلزم قبولها و المصير إليها. (ب) قلت: أخرج سعيد بن منصور في سننه عن زيد بن ثابت قال: القر اعة سنة متبعة. قال البيهقي: أر اد أن أنباع من قبلنا

(1) نقلا عن مناهل العرفان للزرقانى جاص آساط دار الفكر الطبعة الأولى سنة 1977 (1)

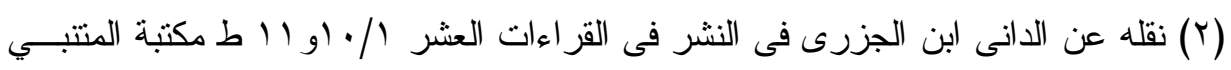

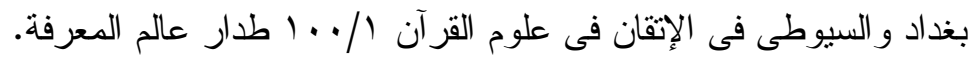


في الحروف سنة متبعة لا يجوز مخالفة المصحف الذي هو إمام، و لا مخالفة القر اءات التي هي مشهورة وإن كان غير ذلك سائغاً في اللغة أو أظهر منها.(') "فالقراءات السبع التي اقتصر عليها الثاطبى والثلاث التي هي قر اءة أبي جعفر ويعقوب وخلف منو اترة معلومة من الدين بالضرورة، وكل حرف انفرد به و احد من العشرة معلوم من الدين بالضرورة أنه منزل على رسول الله (ئس

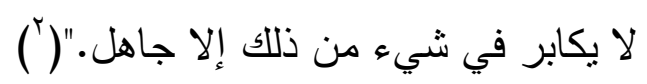

و المنكر لحرف من هذه القراءات المتواترة على شفا جرف هار وخطر عظيم يؤول به إلى الكفر - بعد علمه بالتواتر و الثبوت القطعى - أما قبل ذلك هـون فلا يحكم بكفره، ويخشى عليه من عاقبة جر أته وسوء صنَيعه. " عَنْ عَبٌْ اللَّه

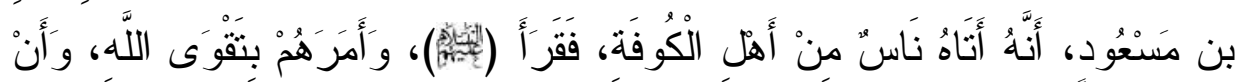

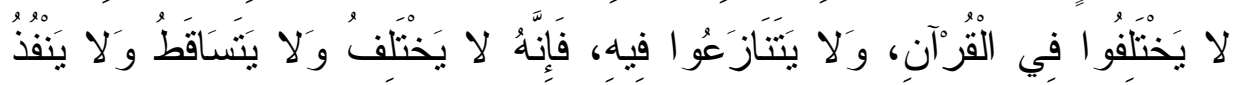

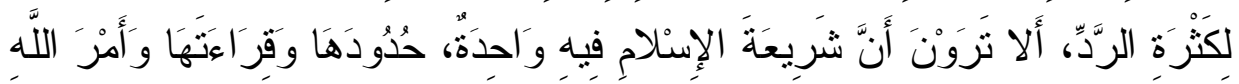

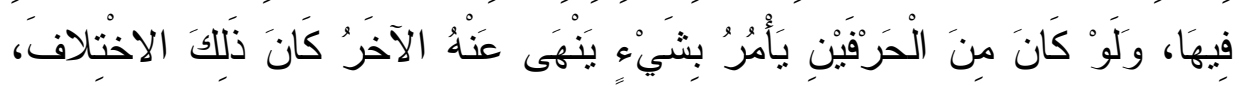

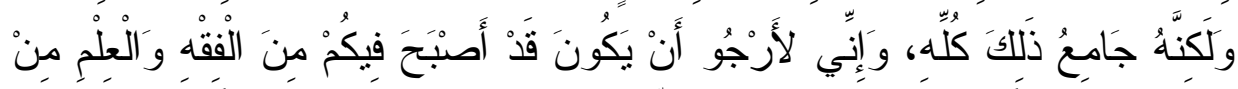

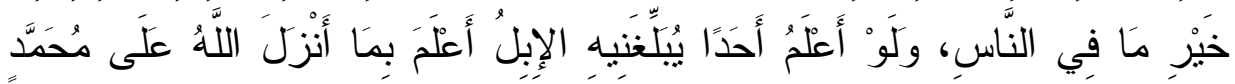

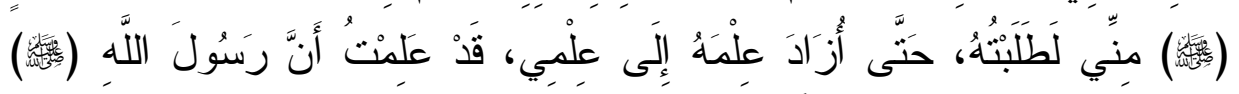

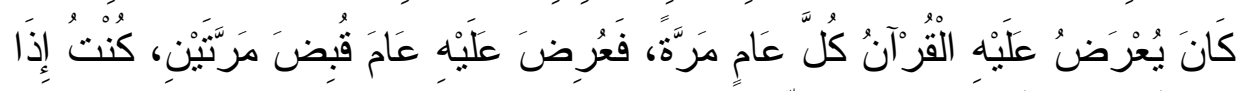

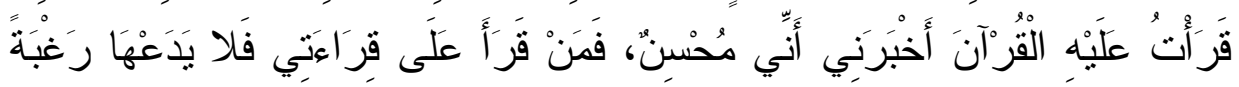

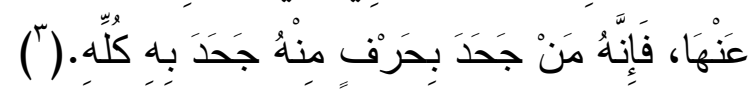

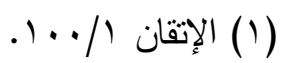

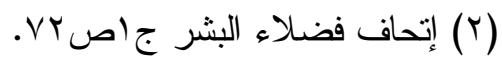

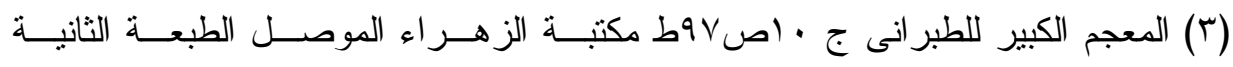

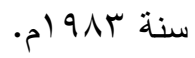




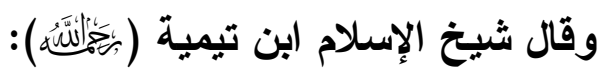

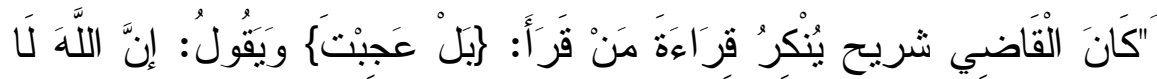

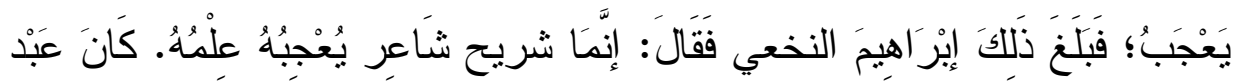

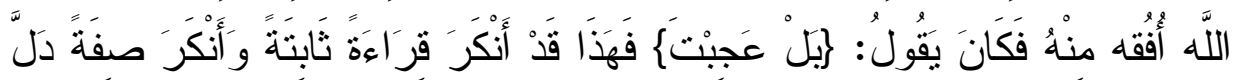

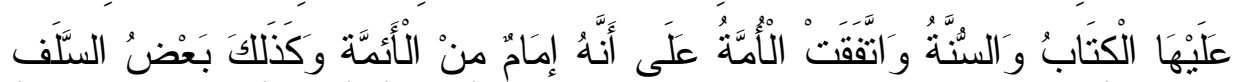

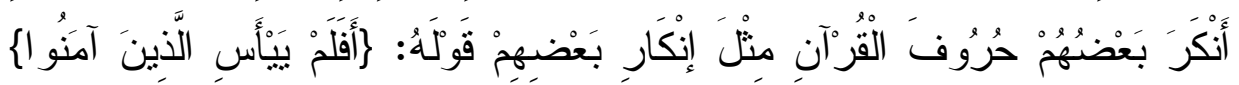

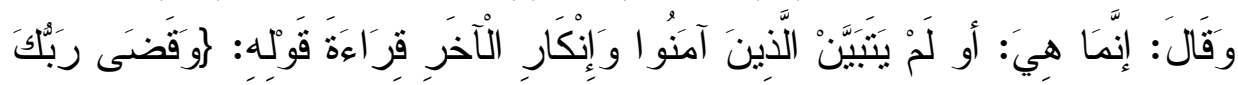

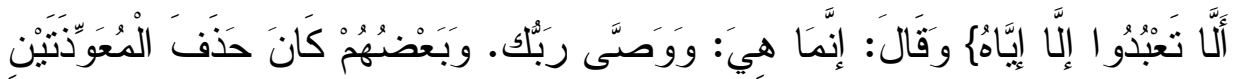

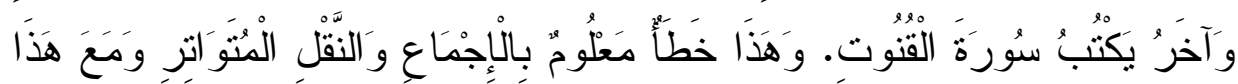

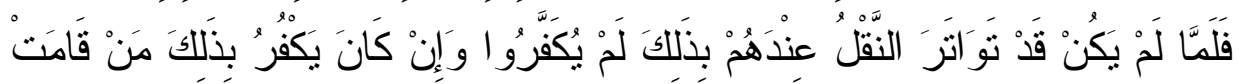

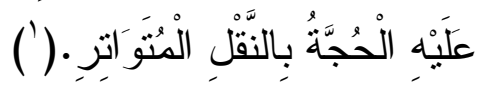

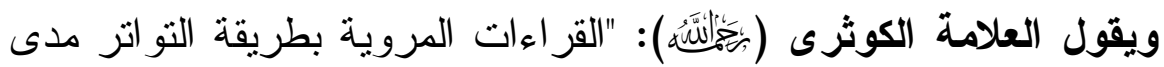
القرون منذ آخر عرضه عرض فيها القرآن المروية بواسطة الأئمة السبعة بل العشرة تو اتر ا، فيكون إنكار شئ من تلك القراءات فى غآية: الخطورة إلا أن من القراءات المتواترة ما يعلم الجماهير تواتره بالضرورة، ومنها ما يعلم تو اتره حذاق القر اء المتفرغون لعلوم القر اءة فقط دون عامتهم، فإنكار شئ من القسم الأول يكون كفر ا باتفاق، و أما إنكار شئ من القسم الثانى فإنما يعد كفر أرن عند إصر ار المنكر على الإنكار بعد إقامة الحجة عليه " (").

(1) فتاوى ابن تيمية جr اص ب9 §ط مكتبة ابن تيمية الطبعة الثانية تحقيق عبد الرحمن بـن محمد بن قاسم العاصمى النجدى.

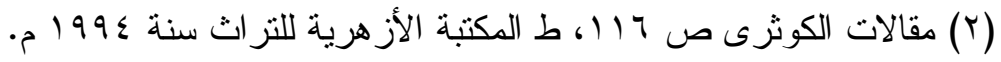


و بهذا ندين ونعتقد، و على الرغم من ذللك وجدت طائفة من النحاة و المفسرين غلبتهم الصنعة النحوية والانتصار لوجهتم اللغوية أن تكلمو ا فى بعض هذه ونه القر اءات بالطعن عليها و ادعو الحن من قر أ بها.

\section{ظاهرة نلحين (') القراء ورد بعض النحاة لبعض القر|ء|نه المنْوانرة}

أولا: نشأة ظاهرة تلحين القراء

غرس بذور ظاهرة تلحين القراء ورد القراءات نحاة البصرة ومن اقتفى أثز هم من اللغويين و المفسرين ومصنفى كتب القر اءات "فقد كانو ا لا يحتجون بالقر اءات إلا فى القليل النادر الذى يتفق مع أصولهم ويتتاسق مع مقاييسهم" ( ) وقد أثار موقف البصريين هذا دهشة الكثير من العلماء و على رأسهم الإمام ابن حزم الظاهرى الذى تعجب من منطق البصريين تجاه القر اءات القر آنية فقال ما نصه: "من النحاة من ينتزع من المقدار الذى يقف عليه من كلام العرب حكما لفظيا ويتخذه مذهبا، ثم تعرض لله آية: على خلاف ذلك الحكم، فيأخذ فى

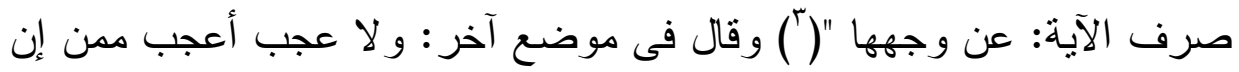
وجد لامرئ القيس أو لزهير أو لجرير ... أو لأعرابى أسدى أو تميمى أو من سائر أبناء العرب لفظا من شعر أو نثز جعله فى اللغة وقطع به ولم يعترض فيه. ثم إذا وجد لله تعالى: خالق اللغات و أهلها كلاما لم يلتقت إليه و لا

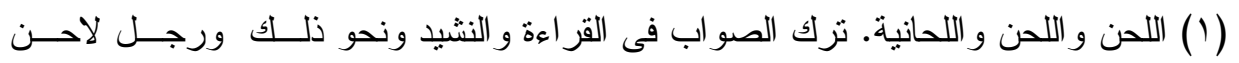

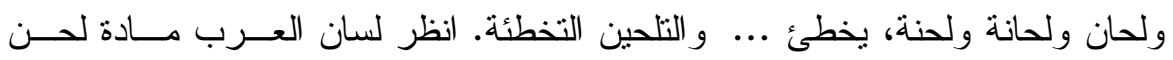

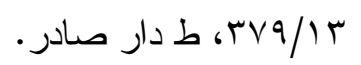

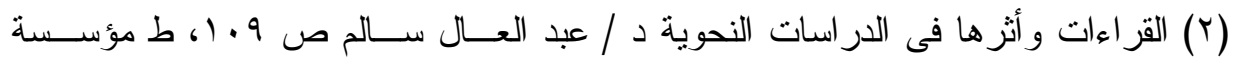

$$
\text { الرسالة. }
$$

(ץ) أصول النحو الأستاذ سعيد الأفغانى ص 94 ، مطبعة الجامعة السورية، طبعة ثانية. 
جعله حجة، وجعله يصرفه عن وجهه ويحرفه عن موضعه " (') أما نحاة الكوفة فكان منهجه أسلم وأصح فى مجال القراءات من منهج البصريين "فالكوفيون لم يتحفظو ا فى مجال القر اءات كما تحفظ البصريون ذلك لأنهم رأوا أن القراءات سندها الروآية: وهى من أجل هذا أقوى فى مجال الاستشهاد من

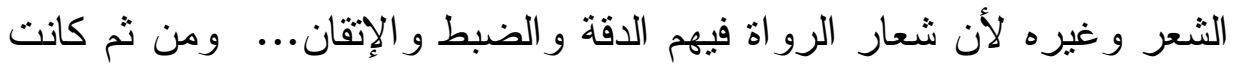
فى نظرهم مصدر التقعيد القو اعد وبناء الأساليب، وتصحيح الكلام بغض النظر

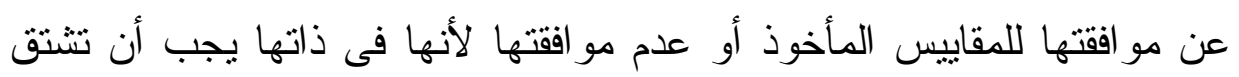
منها المقاييس وتنتمد الأصول " ('). ومنهج الكوفيين هذا هو الأجدر بالقبول، والأسلم فى الاتباع وعليه سار

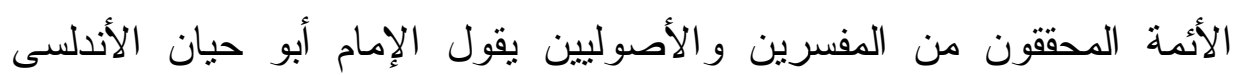

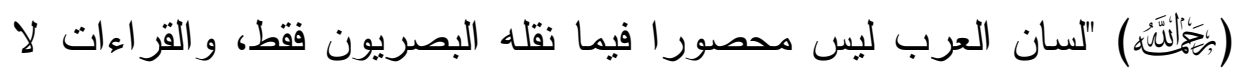
تجيئ على ما علمه البصريون ونقلوه، بل القراء من الكوفيين يكادون يكونون

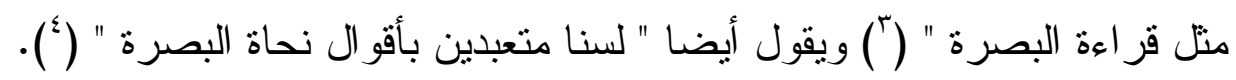

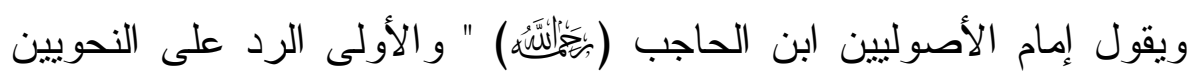
فليس قولهم بحجة عند الإجماع، ومن القراء جماعة من النحويين فلا يكون إجماع النحويين حجة مخالفة القراء لهم، ولو قدر أن القراء ليس فيهم نحوى فإنهم ناقلون لهذه اللغة وهم مشاركون النحويين فى نقل اللغة فلا يكون إجماع

$$
\begin{aligned}
& \text { (1) أصول النحو. الأستاذ سعيد الأفغانى صوج (Y) }
\end{aligned}
$$

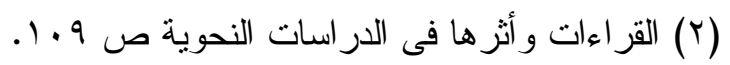

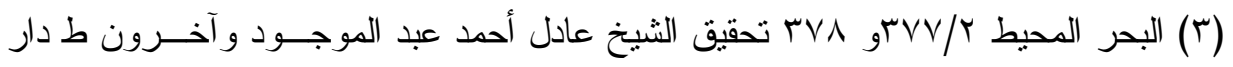

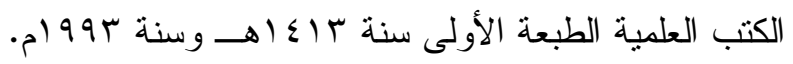

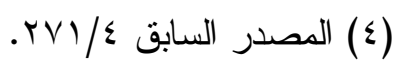


النحويين حجة دونهم وإذا ثبت ذلك كان المصير إلى قول القراء أولى، لأنهم ناقلون عمن ثثتت عصمته من الغلط فى مثله، و لأن القر اءة ثبتت متو اترة وما نقله النحويون آحاد، ثم لو سلم أنه ليس بمتواتر فالقراء أعدل وأثبت فكان

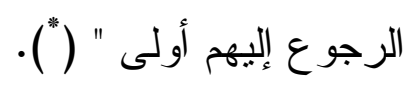

\section{الأسباب النحه |ونه إله وقوع النحاة فه فالهرة النلحين:}

1- احتكامهم إلى القو اعد التى وضعو ها و القوانين التى سنوها: منل منع البصريين الفصل بين المضاف و المضاف إليه (') و العطف على الضمير المجرور من غير إعادة الخافض(بَ) فلحنو القر اءات التى جاءت بذلك. r- عدم ظهور توجيه القراعة لبعض النحويين فيسارع إلى تلحينها مثل قر اءة "هئت للك" بفتح التاء وكسر الهاء لم يعرف الفارسي لها وجها فقال فى كتاب

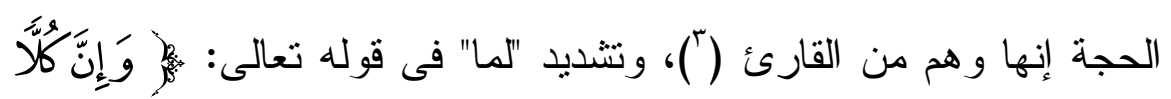

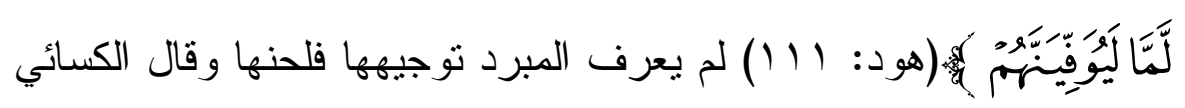

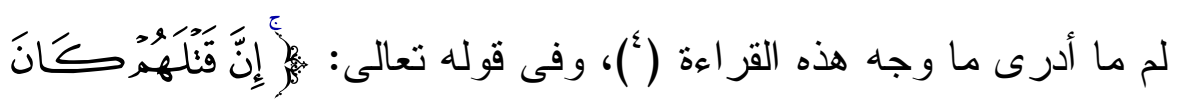
(") در اسات لأسلوب القرآن الثيخ عبد الخالق عضيمة / rV/ ط دار الحـديث، نقــلا مــن لطائف الإشار ات للقسطلانى

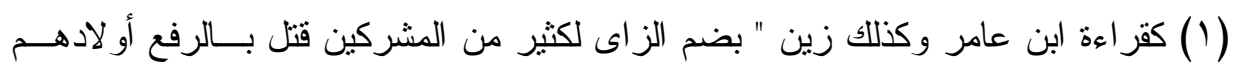
بالنصب شركائهم بالخفض بمعنى وكذلك زين لكثير من المشركين قتل شركائهم أو لادهم ففرقو ا بين المضاف و المضاف إليه.

(Y) كقر اءة حمزة "و اتقو ا الله الذى تساعلون به و الأرحام"بخفض الأرحام الهام.

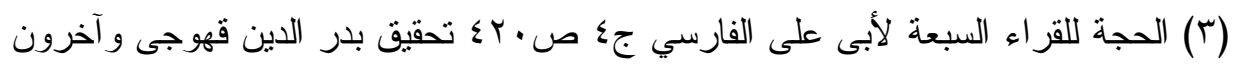

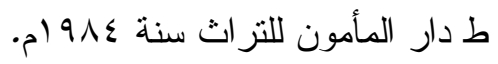

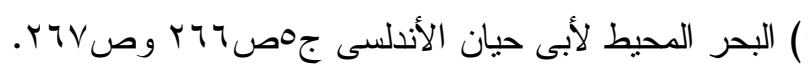




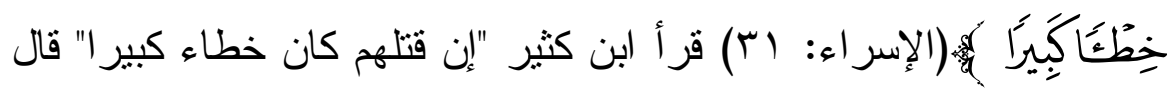
أبو جعفر النحاس لا أعرف لهذه القراءة وجها وجعلها أبو حاتم غلطا.(') r- النظر إلى الثائع من اللغات و الغفلة عن غيره ومن أمتلة ذلك: قوله اعله تعالى:

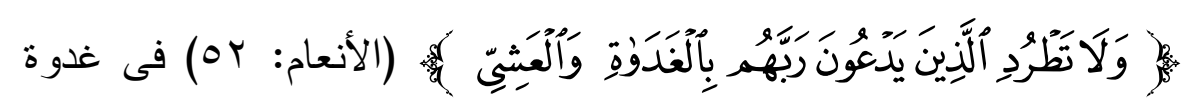

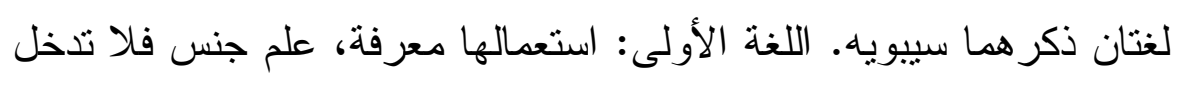

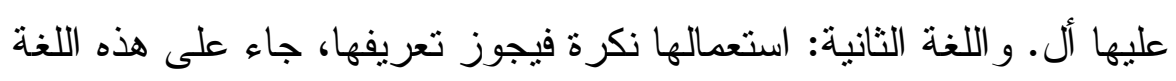

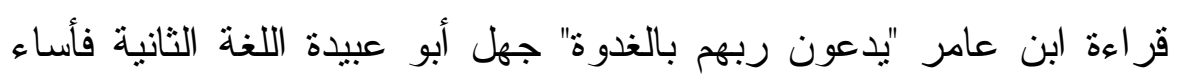

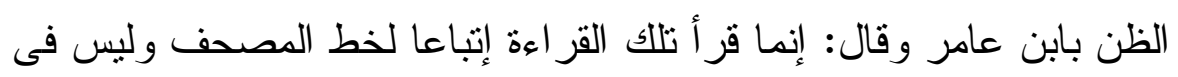

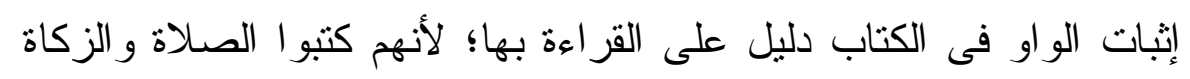

$$
\text { بالو او ولفظهما على تركها. (r) }
$$

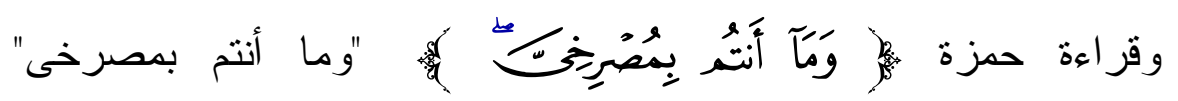

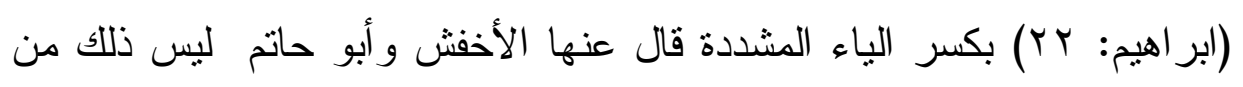

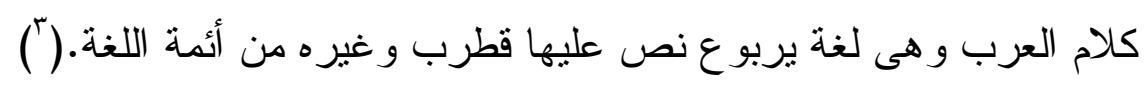

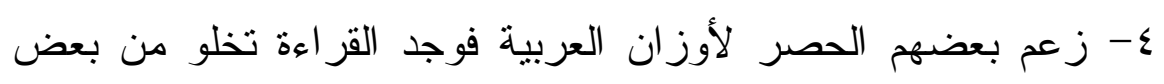

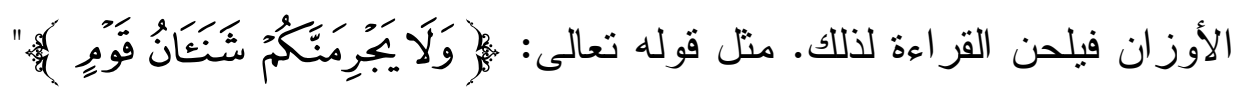

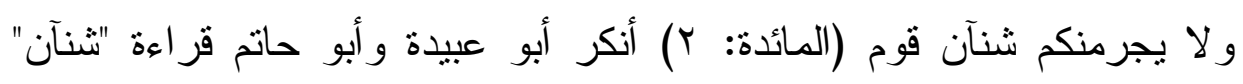

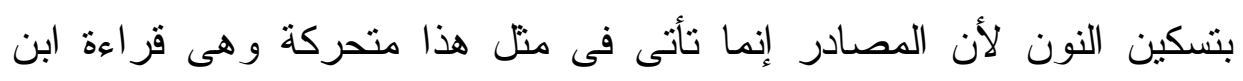

$$
\begin{aligned}
& \text { (1) البحر المحيط ج"صوףז. }
\end{aligned}
$$

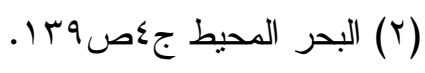

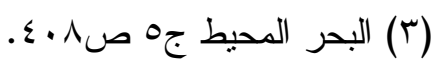




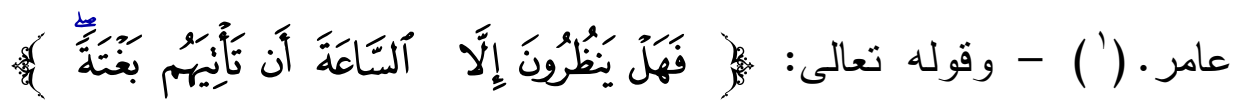

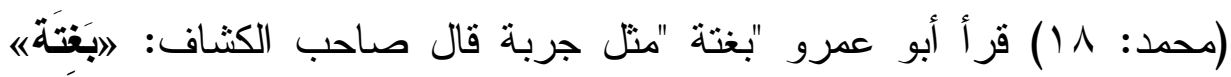

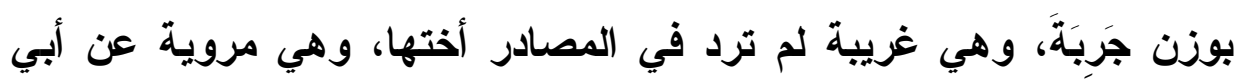

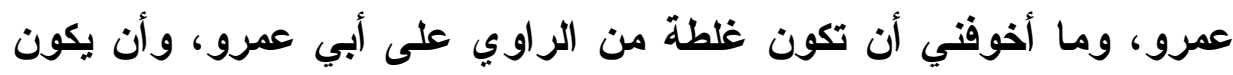

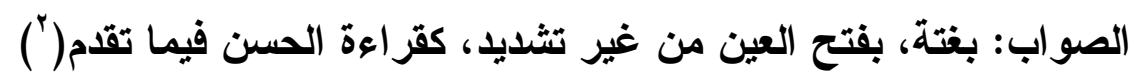

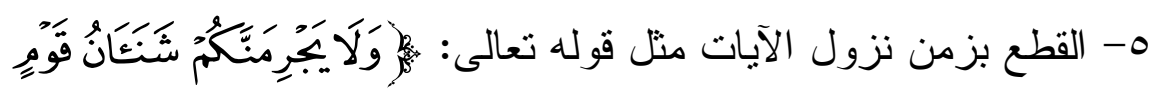

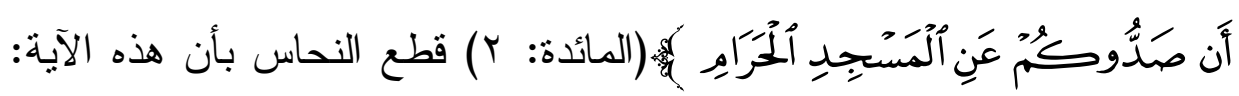

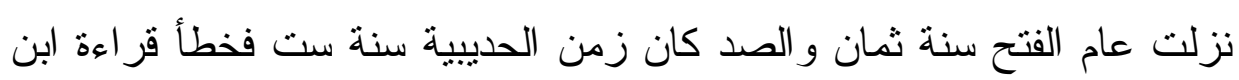

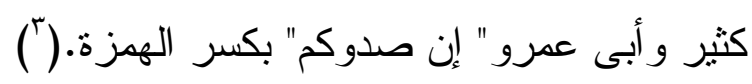
צ- لم يكتف النحويون بنلحين ما خالف قو اعدهم و إنما كان منهم تلحين

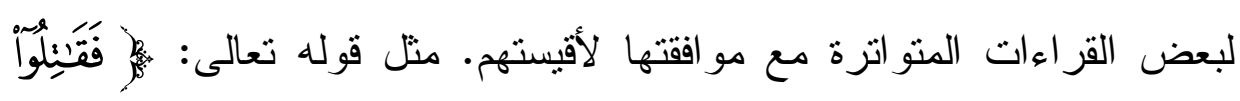

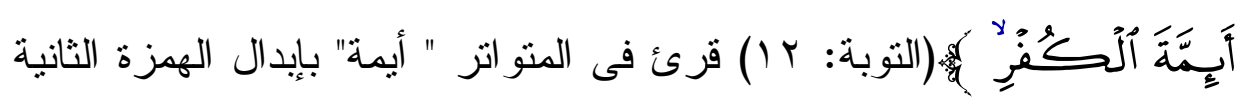

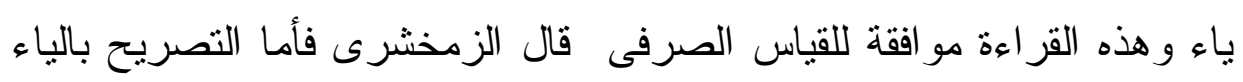

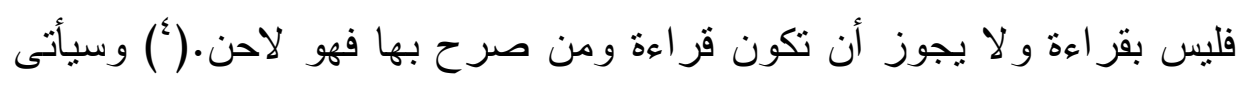
الحديث عن هذه القر اءات بالتفصيل فى المبحث التالى إن شاء الله تعالى:

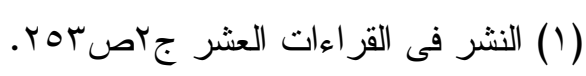

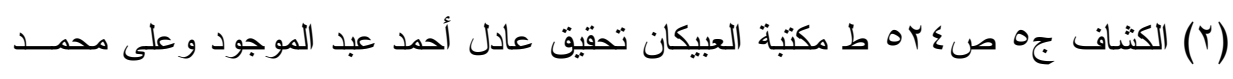

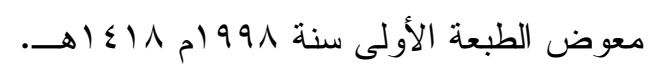

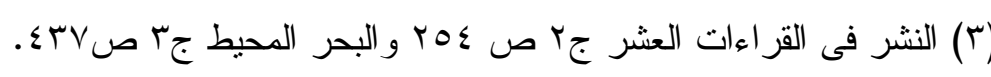

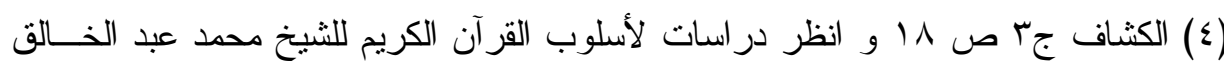

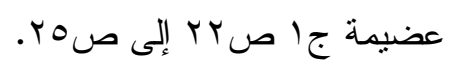




\section{|lillill}

\section{القراكات التب نسب إليدما الامثن ودفمه}

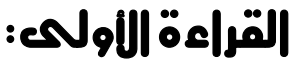

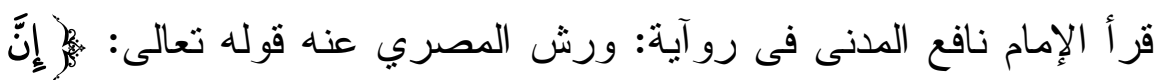

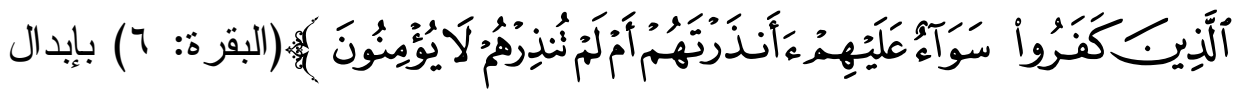
الهمزة الثانية من "أنذرتهم" ألفا محضا غير أن هذه القراءة طعن عليها الزمخشرى ونسبها إلى اللحن وتبعه البيضاوى فى ذلك؛ لأنها تؤدى إلى الجمع بين ساكنين، و أن طريق تخفيف الهمزة المتحركة المفتوح ما قبلها هو التسهيل بين بين لا قلبها ألفا؛ لأن ذلك هو طريق تخفيف الهمزة الساكنة المفتوح قبلها و إليك تفصيل ذلك:

قال العلامة الزمخشري: "وقرىء: 》أنذرتهمه بتحقيق الهززتين، و التخفيف أعرب وأكثر، وبتخفيف الثانية بين بين، وبتوسيط ألف بينهما محققتين، وبتوسيطها و الثانية بين بين، وبحذف حرف الاستفهام، وبحذفه و إلقاء حركته على الساكن قبله، كما قرىء لاقد أفلحه. فإن قلت: ما تقول فيمن يقلب الثانية ألفاً قلت: هو لاحن خارج عن كلام العرب خروجين: أحدهما: الإقدام على جمع الساكنين على غير حدّه، وحدّه أن يكون الأوّل حرف لين و الثاني حرفاً مدغماً نحو قوله: الضالين، وخويصة. والثاني: إخطاء طريق التخفيف؛ لأن طريق تخفيف الهمزة المتحرّكة المفتوح ما قبلها أن تخرج بين بين؛ فأما القلب ألفاً فهو تخفيف الههزة الساكنة

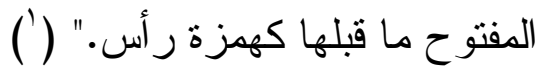

(1) الكثاف جا صو9ءط مكتبة مصر شرحه وضبطه يوسف الحمادى. 


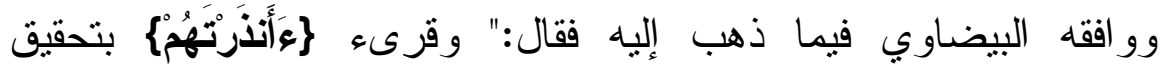

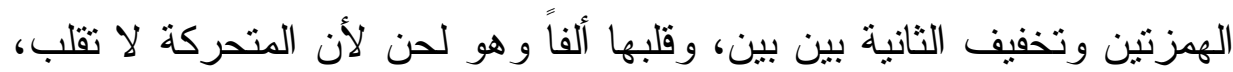
و لأنه يؤدي إلى جمع الساكنين على غير حده، وبنوسيط ألف بينهما محققتين، وبتوسيطها و الثانية بين بين وبحذف الاستفهامية، وبحذفها و إلقاء حركتها على لئى

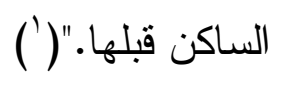

\section{تفنيد ما تقلم من طعون:}

أولا: من جهة السند والنقل: تقام الحديث عن ثناء العلماء على إمام أهل

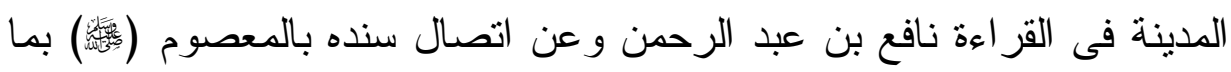

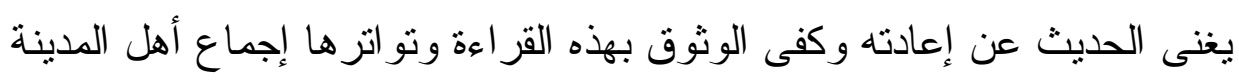

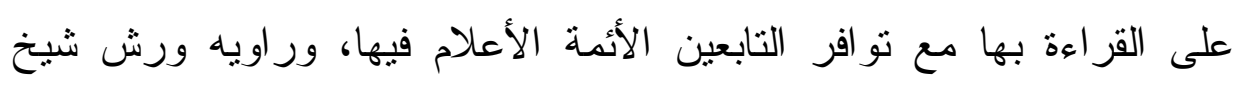

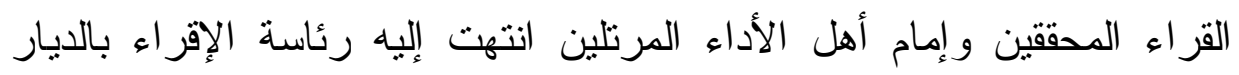

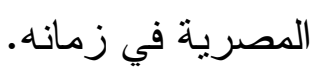

ثانيا: تفنيدها من جهة العربية: قال الإمام أبو حيان: ولغة تميم تحقيق

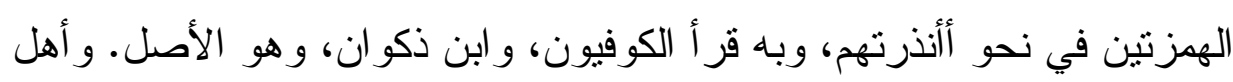

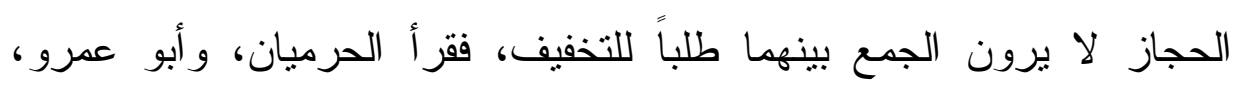

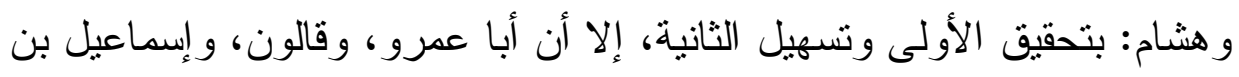

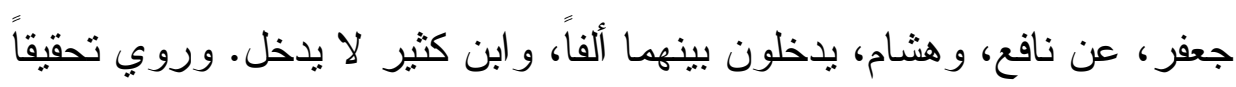

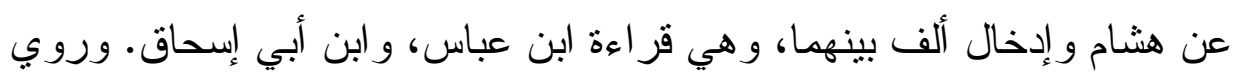

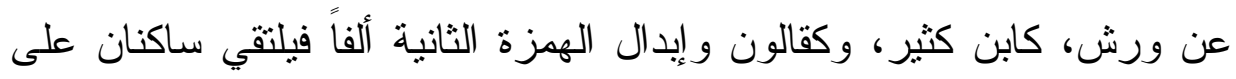

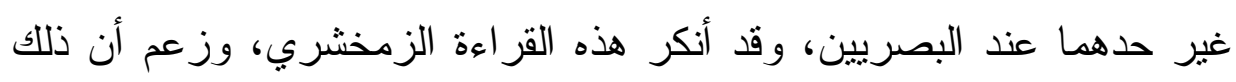

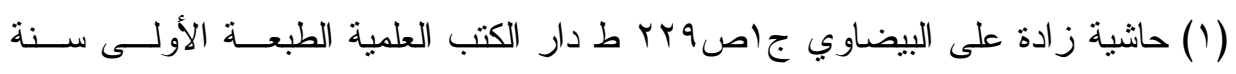
$.0199901 \leqslant 19$ 
لحن وخروج عن كلام العرب من وجهين: أحدهما: الجمع بين ساكنين على غير حده. الثاني: إن طريق تخفيف الههزة المتحركة المفتوح ما قبلها هو بالتسهيل بين بين لا بالقلب ألفاً، لأن ذلك هو طريق الهمزة الساكنة، وما قاله هو مذهب البصريين، وقد أجاز الكوفيون الجمع بين الساكنين على غير الحد لاندين

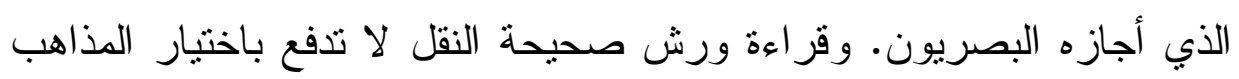
ولكن عادة هذا الرجل إساءة الأدب على أهل الأداء ونقلة القر آن. (') وقال الشيخ محى الدين شيخ زاده معلقا على قول البيضاوي السابق: "قوله "وقلبها ألفا وهو لحن" أى خروج عن كلام العرب من وجهين: الأول: أن قلب الهزة المتحركة المفتوح ما قبلها ألفا ليس طريقا لتخفيفها عندهم، فإن طريق تخفيفها إنما هو جعلها بين بين و أما قلبها ألفا فهو طريق

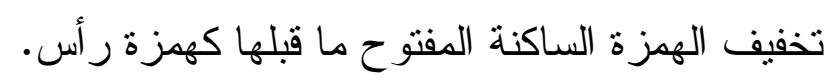
والثانى: أنه إقدام على جمع الساكنين على غير حده لأن الساكن الثانى غير مدغم.

وقد أجيب عن الأول بأن الهزة المتحركة قد تقلب ألفا على الثذوذ كما نقل عن بعض القر اء السبعة أنهم قرؤو ا "منساته" بقلب همزة المنسأة ألفا.

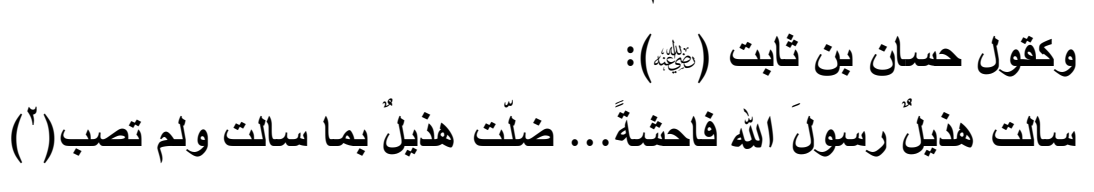

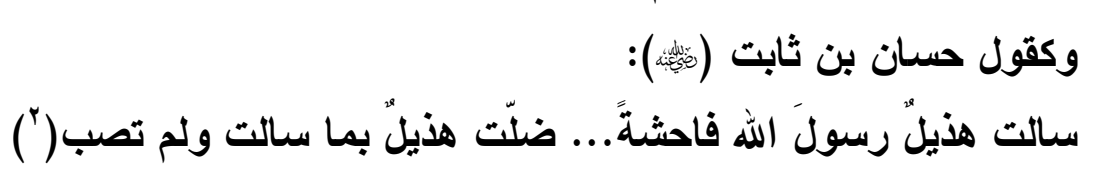

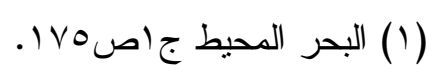

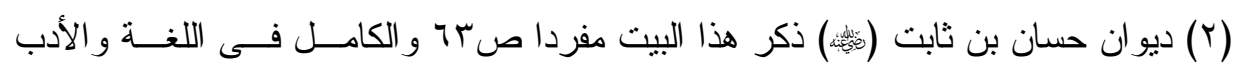

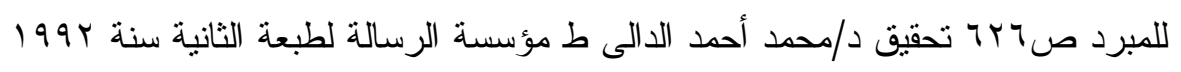

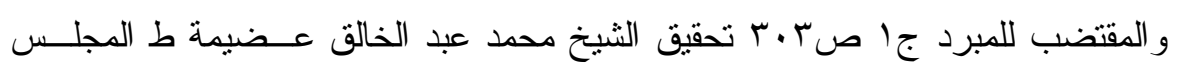
الأعلى للشؤون الإسلامية سنة؛ 99 ام. 
فقلب همزة سألت ألفا.

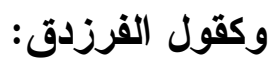

ومضت بمسلمة البغال عشية ** فارعى قزازة لا هناك المرتع(') أصله لا هنأك المرتع قلبت الهمزة المتحركة ألفا. و إذا ثبت منل ذلك فى كلام الفصحاء ونقل عمن ثبت عصمته من الغلط يجب قبوله و القر اء أعدل من النحاة فيرجح ما نقل عنهم على قول النحاة. وعن الثانى: بأنها إذا قلبت ألفا تشبع الألف مقدار از ائدا على مقدار الألف

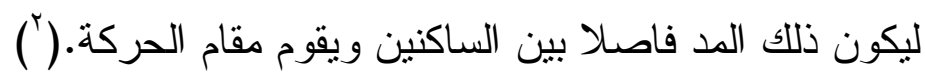
مما سبق يتبين لنا صحة هذه القراعة وسلامتها من الطعون وموافقتها للفصيح المنقول من كلام العرب الدال على جواز قلب الهمزة المتحركة ألفا، وما اعترض به لأجل الجمع بين الساكنين فيها مدفوع بأن الألف المقلوبة عن الهمزة تشبع إثباعا يجعلها فى مقام الحركة، فلا وجه لما ذهب إليه الطاعنون وثبت تواتر هذه القر اءة.

\section{القر|عة الثانية:}

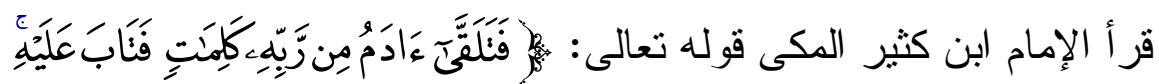

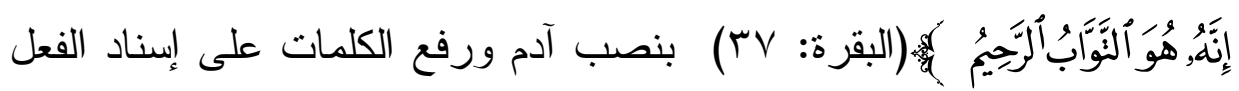
إلى الكلمات وإيقاعه على آدم، غير أن هذه القراعة لم يجزها الإمام الطبرى

(1) البيت فى ديو ان الفرزدق بلفظ ومضت لمسلمة الركاب مودعا فارعى قـزازة لا هنــاك

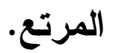

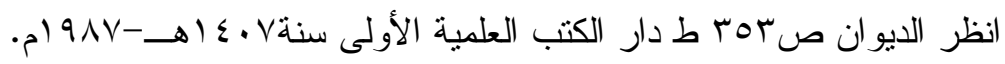

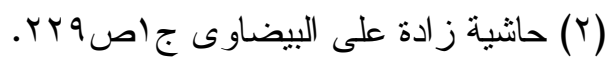


لمخالفتها إجماع القر اء وجواز الخطأ والنسيان على من قرأ بها، و إليك تفصيل ذللك:

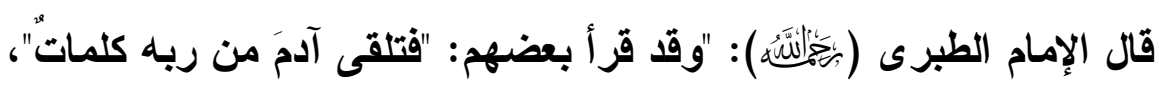

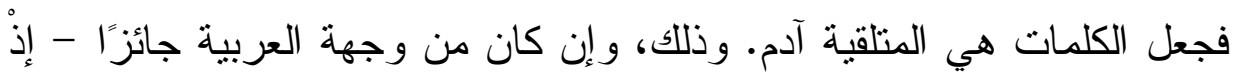
كان كل ما تلقاه الرجل فهو له مُتلقّ، وما لقيه فقد لَقيه، فصار للمتكلم أن يُوجها ونه الفعل إلى أيهها شاء، ويخرج من الفعل أيهما أحب - فغير جائز عندي في القر اءة إلا رفع "آدم" على أنه المتلقي الكلمات، لإجماع الحجة من القَرَأة و أهل هل التأويل دن علماء السلف والخلف، على توجيه التلقي إلى آدم دون الكلمات. وغير' جائز الاعتر اض عليها فيما كانت عليه مجمعة، بقول من يجوز عليه

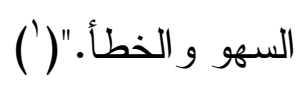

\section{نْفنيد طمن الإماه |لطبرك:}

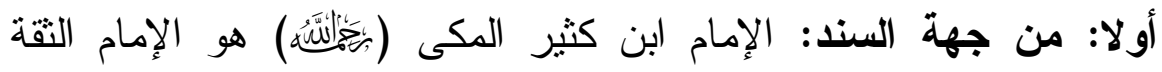
الضبط العدل أحد التابعين اجتمع على قر اعته أهل مكة مع تو افر التقات فيها

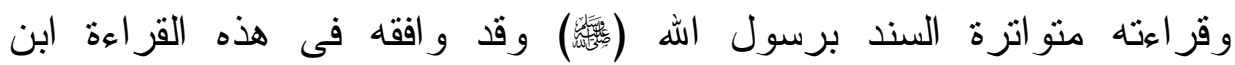
محيصن (r) فلا وجه لما ذهب إليه الطبري من احتمال الخطأ و النسيان عليه فمنل هذا احتماله بعيد عن الثقة الضبط ولم يذهب إليه غيره فقوله مردود عليه. ثانيا: من جهتى المعنى والعربية: وجه المفسرون هذه القر اءة بما يستقيم به المعنى و لا يأباه السياق فقالو ا: "أصل التلقي التعرض للقاء، ثم يوضع موضع

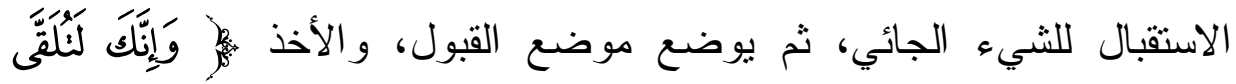

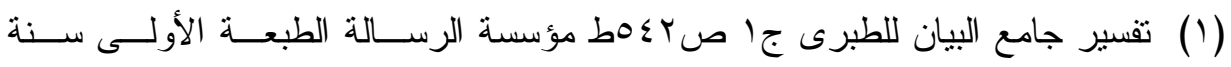

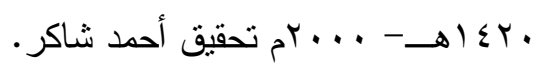

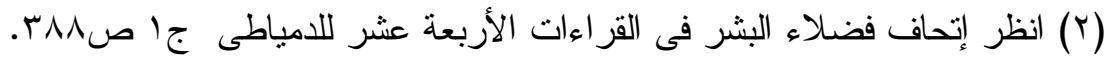




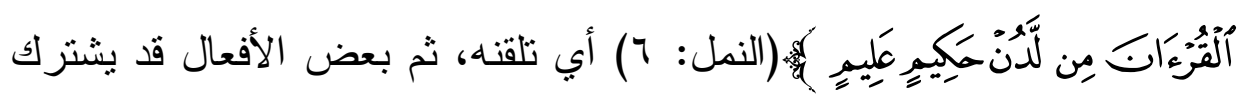
فاعله ومفعوله في صلاحية وصف كل منهما بالفعل فيتعاوضان عمله فئه فيهما.

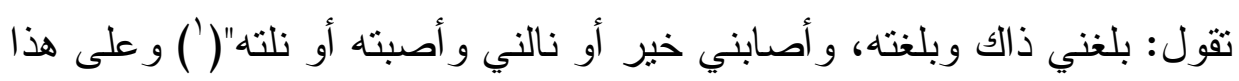

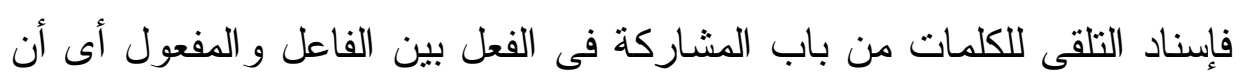

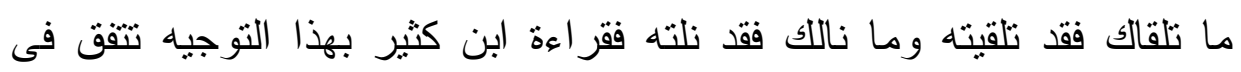

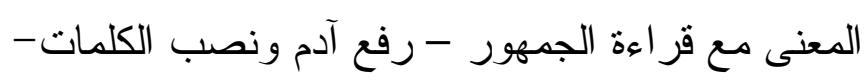

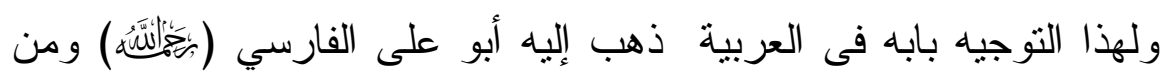

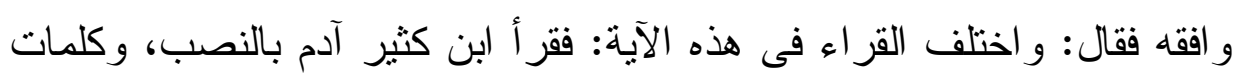

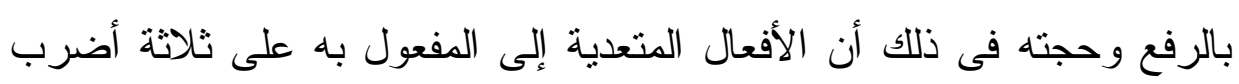
منها:

ما يجوز أن يكون الفاعل لله مفعو لا به، ويجوز أن يكون الدفعول به فاعلا

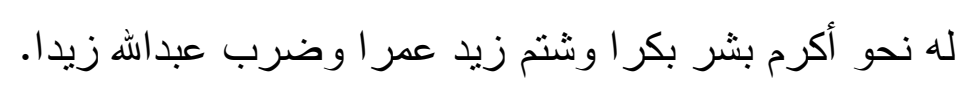

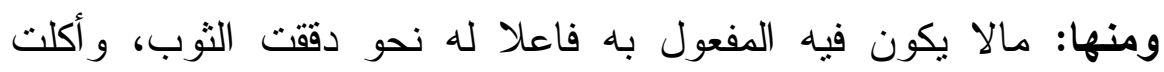

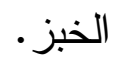

ومنها: ما يكون إسناده إلى الفاعل فى المعنى كإسناده إلى المفعول به

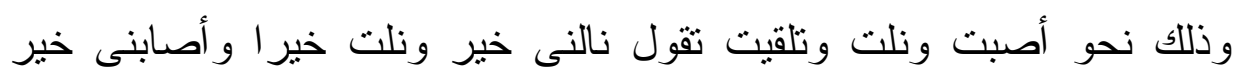

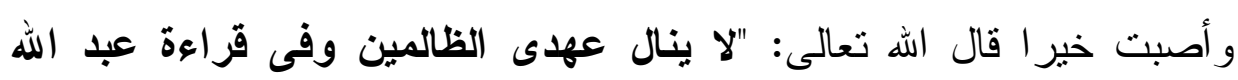
"الظالمون" وتقول: لقيت زيدا وتلقانى وتلقيته قال:

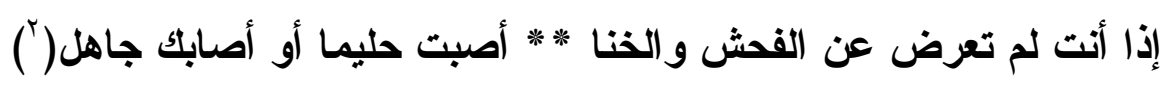

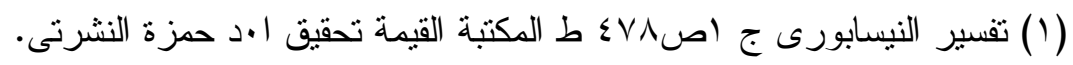

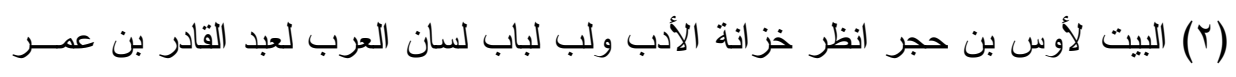
البغادى ج؛ ص .دr تحقيق وشرح عبد السلام هارون ط مكتبة الخانجى القاهرة. 


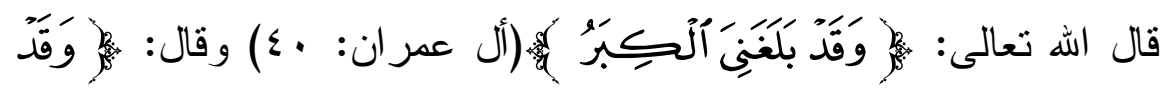

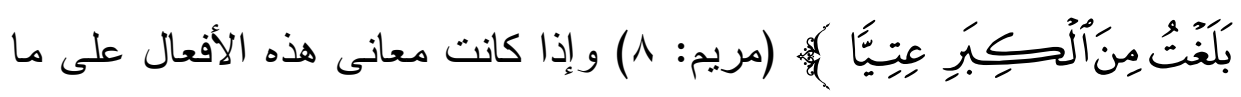

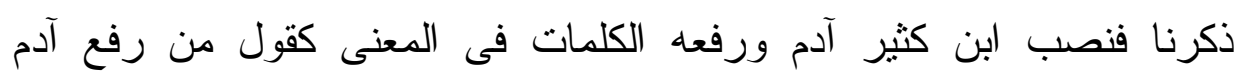

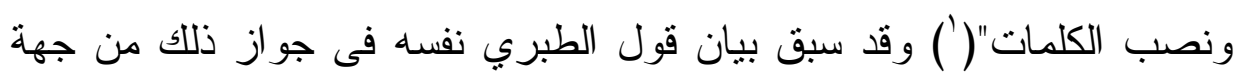

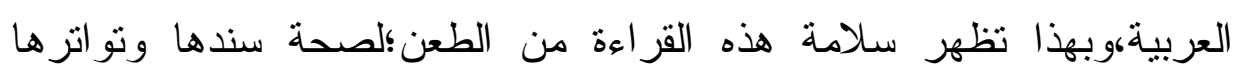

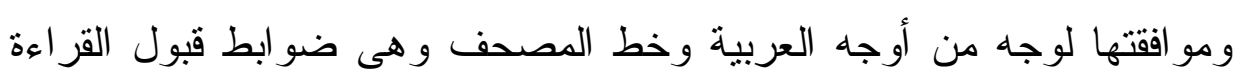
عند الأئمة و لا عبرة بقول من خالف ذلك. لكن.

\section{|لقر|هة|الثالثة:}

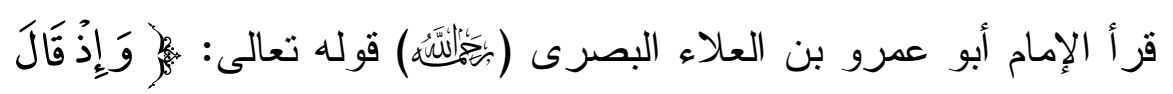

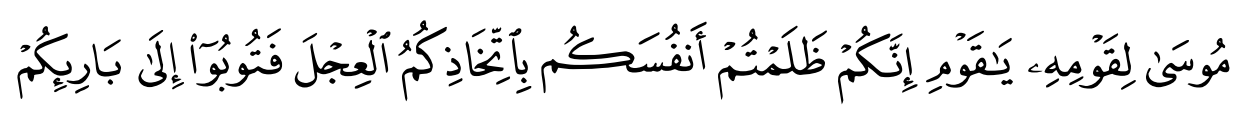

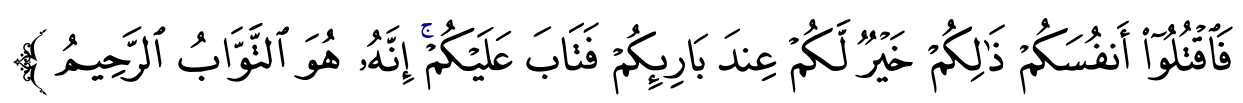

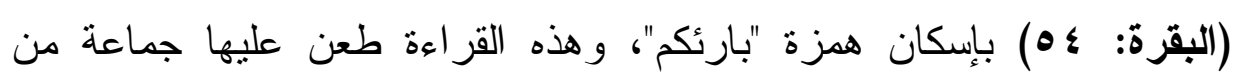

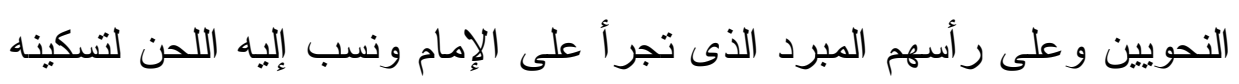
حركة الإعر اب و إليك تفصيل ذلك:

"قرأ الجمهور: 》 هارئكم " بإظهار الهمزة وكسرها، وقرأ أبو عمرو: 》 بارئكم 《 بإسكان الهمزة.

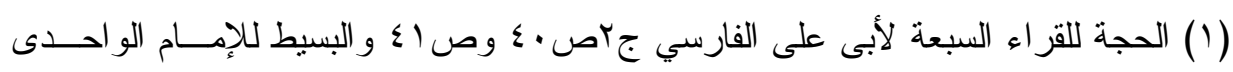

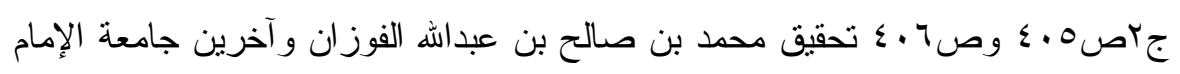
محمد بن سعود سلسة الرسائل الجامعية. 
طعن المبرد على قر اعة أبى عمرو البصرى فقال: لا يجوز التسكين مع تو الي الحركات في حرف الإعراب، وقر اءة أبي عمرو " بارئكم " لحن."(') وروي عن سيبويه(') اختلاس الحركة وهو أحسن، وهذا التسكين يحسن في تو الي الحركات.

قال ابن جنى: قرأ أبو عمرو مختلسا غير ممكن كسر الهمزة حتى دعا ذلك من لطف عليه تحصيل اللفظ إلا أن أبا عمرو كان يسكن الهمزة، و الذى فئ فئ رو اه صاحب الكتاب اختلاس هذه الحركة لا حذفها ألبتة وهو أضبط لهذا الأمر

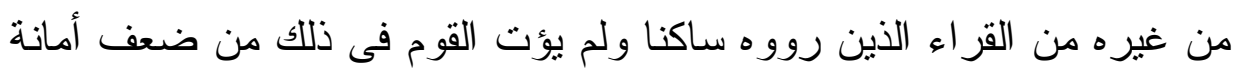
لكن أتو ا من ضعف در من آية: "(") تفنيد طعن المبرد ومن و افقه:

الإمام أبو عمرو بن العلاء: هو الإمام العربى اللسن الفصيح إمام نحاة البصرة و أعلمهم باللغة و أحد القر اء السبعة فهو أبعد ما يكون عن اللحن و الخطأ

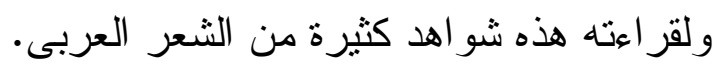

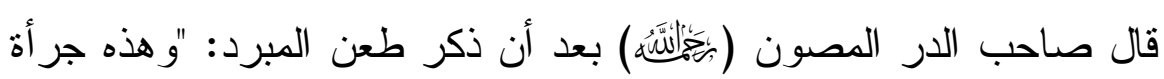

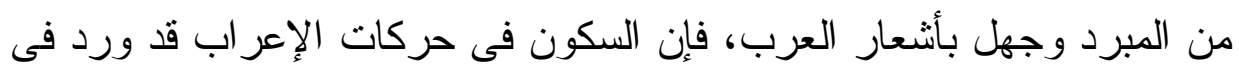
الشعر كثير ا ومنه قول امرئ القيس:

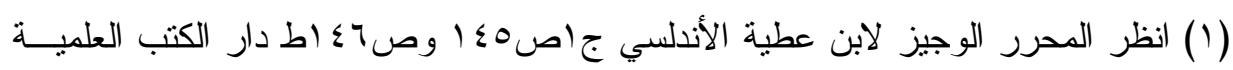

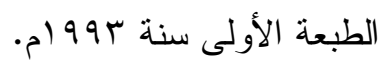

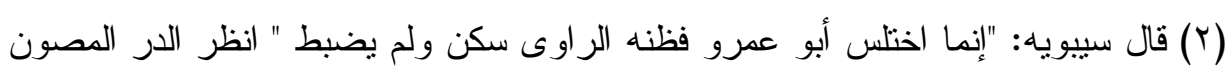

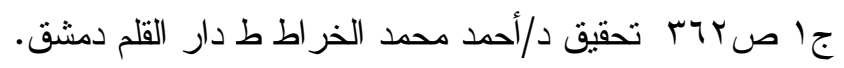

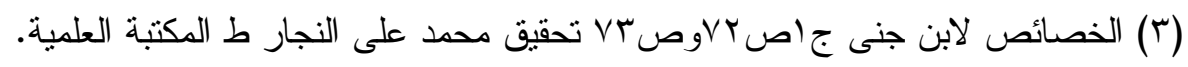




\section{إقامة الحجة على ملعى تلحين القراء السبعة}

فاليوم أثثرب غير مستحقب ** إثماً من الله ولا واغل(')

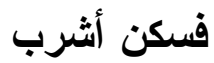

وقال جرير : ونهر تيري فما تعرفْكُمُ العربُ..(")

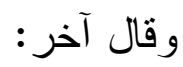

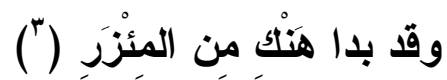
يريد هنك وتعرفكم - بضم النون والفاء- فهذه حركات إعراب وكانت إعر ابا وقد سكنت، وقد أنثد ابن عطية وغيره ردا عليه.

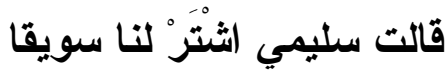

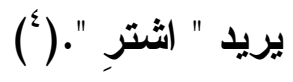

$$
\text { وقول آخر: إذا اعوججن قلت صاحب قوم..(") ") }
$$

وقراءة أبى عمرو صحيحة وذلك أن الهمزة حرف ثقيل ولذلك اجترئ عليها بجميع أنو اع التخفيف فاستثلت عليها الحركة فقدرت، وهذه القر اءة تثببه

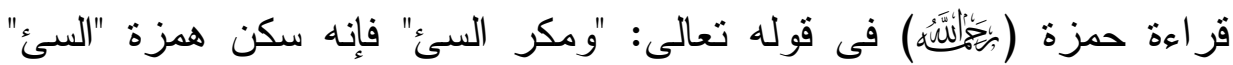

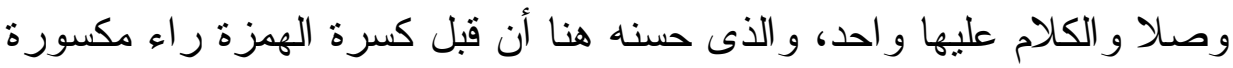

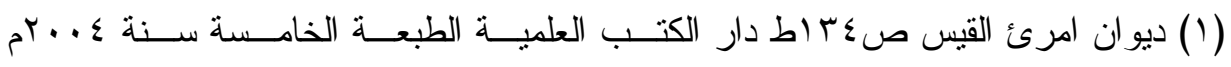
$\rightarrow 1 \leqslant$ Y

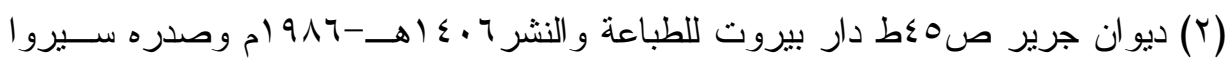

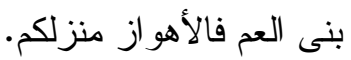

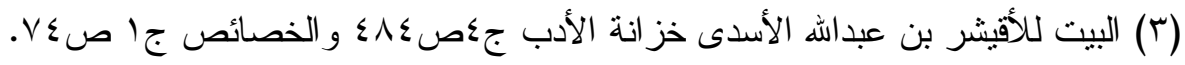

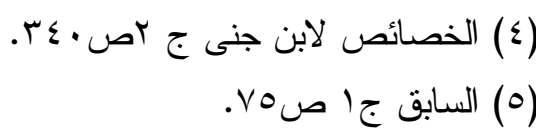


و الر اء حرف تكرير فكأنه تو الى ثلاثة كسر ات فحسن التسكين، وليت المبرد اقتنىى بسيبويه فى الاعتذار عن أبى عمرو وفى عدم الجرأة عليه."(')

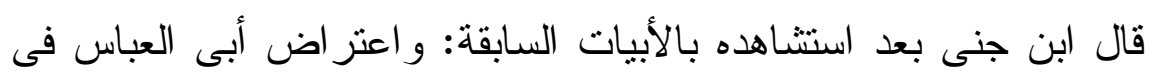
هذا الموضع إنما هو رد للروآية: وتحكم على السماع بالثهوة مجردة من بن

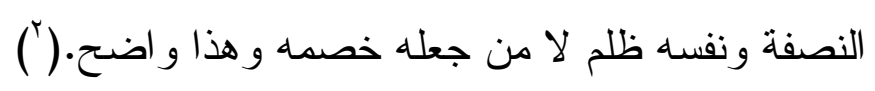

بهذه الثو اهد الثعرية تظهر موافقة قراءة أبى عمرو للعربية وسلامتها

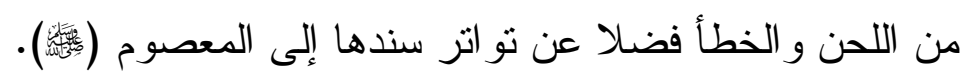

\section{|اقمراعة الر|بعة:}

قال تعالىى:

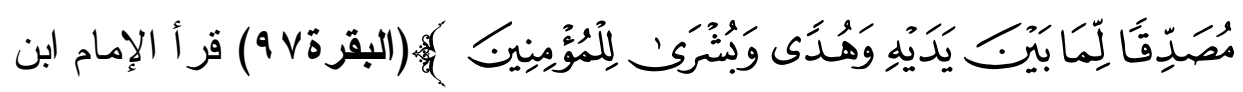
كثير المكى "جبريل" هنا وفى التحريم بفتح الجيم وكسر الر اء وياء ساكنة من

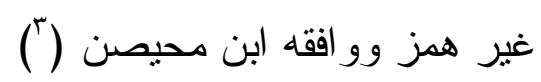

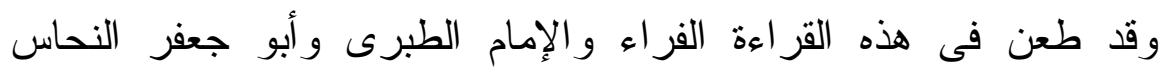
بدعوى أن جبريل بفتح الجيم على وزن فعليل-بفتح الفاء- وهذا الوزن ليس فى ولى ولي كلام العرب و إليك تفصيل ذلك.

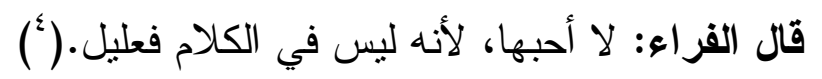

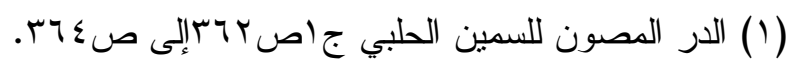

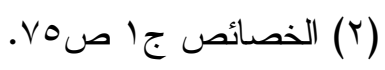

(r) التبسير فى القر اءات السبع لأبى عمرو الداني صه V و و إتحاف فضلاء البشر بـالقر اءات

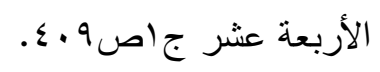

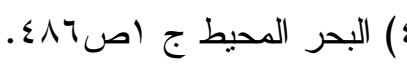


قال الإمام الطبري: وقد ذكر عن الحسن البصري وعبد الله بن كثير أنهما كانا يقر آن: "جبريل" بفتح الجيم. ونرك الهمز . قال أبو جعفر: وهي قر اءة غير جائزةٍ القر اعةٌ بها، لأن "فعليل" في كلام العرب غير موجود. وقد اختار ذلك بعضهم، وزعم أنه اسم أعجمي، كما يقال:

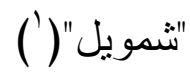
وقال النحاس: -وذكر قراعة ابن كثير - - "لا يعرف في كلام العرب

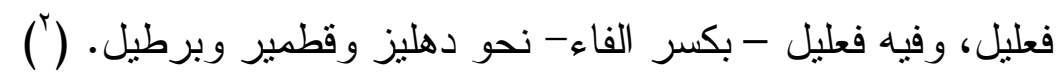
تقنيد ما تقدم من طعون: قال الإمام أبو حيان الأندلسي معقبا على طعن الفر اء: وما قاله ليس بشيء، لأن ما أدخلته العرب في كلامها على قسمين: منه الأهن ما تلحقه بأبنية كلامها، كلجام، ومنه ما لا تلحقه بها، كابريسم. فجبريل، بفتح

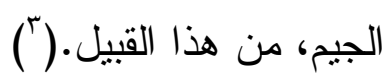
وقال الإمام القرطبي معقبا على قول أبى جعفر النحاس: "لا يعرف في كلام العرب فعليل، وفيه فعليل، نحو دهليز وقطمير وبرطيل، وليس ينكر أن الن يكون في كلام العجم ما ليس لله نظير في كلام العرب، وليس ينكر أن يكثر تغيره، كما قالو ا: إبر اهيم و إبرهم و إبر اهم و إبر اهام. قال غيره: جبريل اسم أعجمي عربته العرب، فلها فيه هذه اللغات ولذلك لم وليز

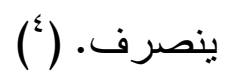

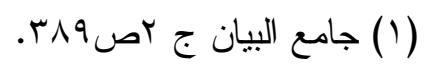

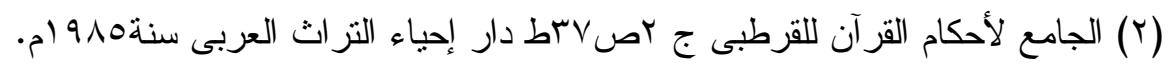

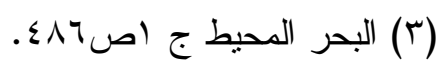

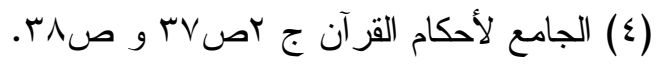


وقا حسن هذه القراعة أبو على الفارسي لاستعمال العرب لها فقال: "وليس فى كلام العرب على هذه الأبنية فكذلك قول من قال "جبريل" إذا كسر الجيم كان على لفظ "قنديل وبرطيل" و إذا فتحها فليس لهذا البناء مثل فى كلام العرب فيكون من باب الآجر و الفرند ونحو ذلك من المعرب الذى لم يجئ لله منل فى كلامهم فكلا المذهبين حسن لاستعمال العرب لهما جميعا و إن كان

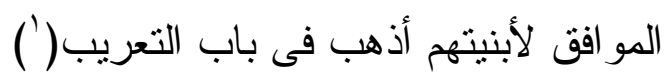

وخلاصة ما تقدم: أن كلمة "جبريل" كلمة أعجمية عربتها العرب باستعمالها

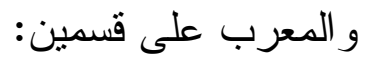

1 - ما تلحقه العرب بأبنية مصادرها مثل لجام.

ץ - ما لا تلحقه كابريسم ومن هذا القبيل "جبريل" بفتح الجيم وقد استعملها العرب بالوجهين فتح الجيم وكسرها فلا وجه لإكار ذلك وثبت صحة

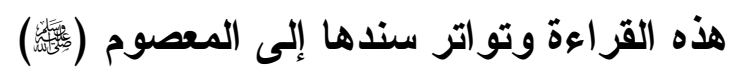

\section{|لقر|عة الخامسة:}

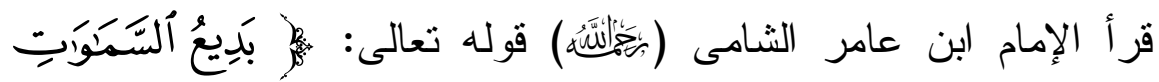

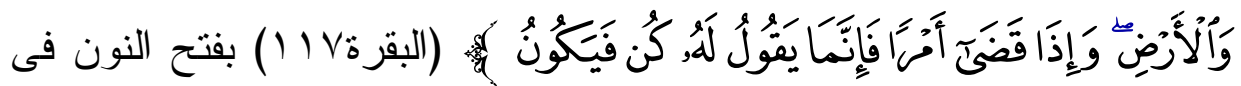
قوله "فيكون" وقرأ الباقون بضمها، وقد طعن فى هذه القر اعة بعض القراء و النحاة كابن مجاهد و الزجاج و أبى على الفارسي و أبى البقاء العكبرى.

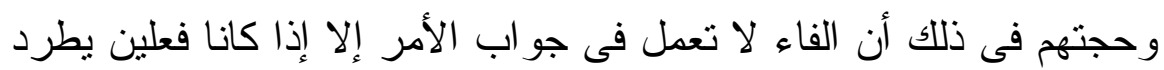
فيهما معنى الشرط تقول أكرم زيدا فيكرمك و المعنى إن تكرم زيدا يكرمك وفى ولى النى هذه الآية: لا يستقيم المعنى على هذا التقدير ؛ لأنه يؤول إن يكن يكن و لا معنى 
له، و الفعل الذى يطرد فيه معنى الشرط هو أن يختلف الفعلان منل أكرم زيدا

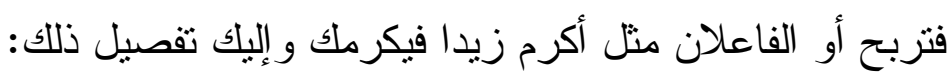
طعن الإمام أبو بكر أحمد بن موسى بن مجاهد فى هذه القراعة فقال:

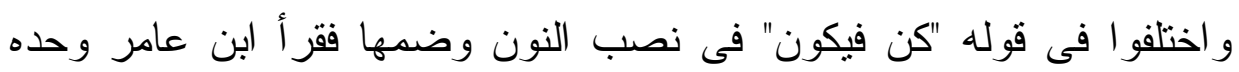

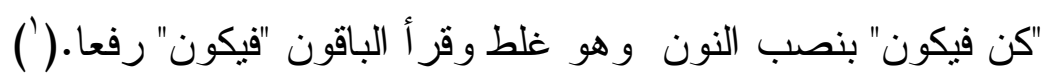
و أنكر الزجاج قر اعة النصب فقال: "فيكون " رفع لاغيره.(") ونهون وضعفها أبو على الفارسي وتبعه فى ذلك أبو البقاء العكبرى.

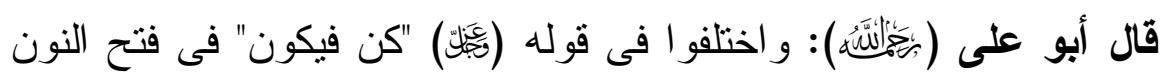
وضمها، فقر أ ابن عامر وحده "كن فيكون" بنصب النون وقر أ الباقون "فيكون" رفعا .... - n

وقد يمكن أن تقول فى قول ابن عامر: إن اللفظ لما كان على لفظ الأمر و إن لم يكن المعنى عليه حملته على صورة اللفظ،فقد حمل أبو الحسن نحو قوله "قل لعبادى الذين آمنو ا يقيمو الصلاة" ونحو ذللك من الآى على أنه أجرى مجرى جو اب الأمر و إن لم يكن جو ابا له فى الحقيقة فكذلك على قول ابن عامر يكون قوله فيكون بمنزلة جواب الأمر نحو ائتى فأحدثلك لما كان على لفظه، وقد يكون اللفظ على شئ و المعنى على غيره. ألا نزى أنهم قد قالو ا ما أنت وزيدا؟ و المعنى لم تؤذيه؟ وليس ذلك فى اللفظ . . . ومن ثم أجمع الناس على ونى

(1) السبعة فى القراءات لابن مجاهد ص179 179 دار المعارف مصر الطبعة الثانيــة ســنة

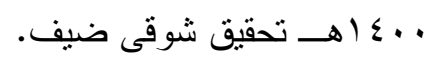

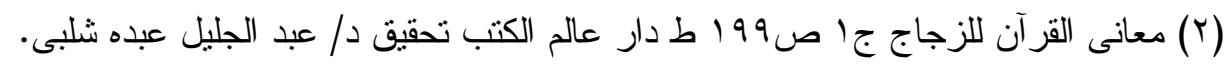
$-r V$ - 
رفع "فيكون" ورفضو ا فيه النصب إلا ماروى عن ابن عامر وهو من الضعف

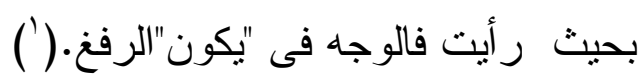
وقال أبو البقاء: قوله تعالى: "فيكون" الجمهور على الرفع عطفا على يقول أو على الاستئناف أى فهو يكون، وقرئ بالنصب على جواب لفظ الأمر وهو

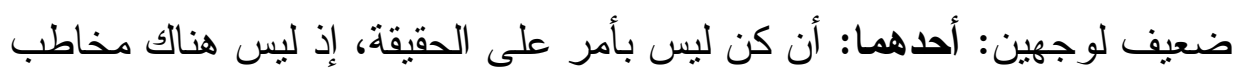
به، و إنما المعنى على سرعة التكون، يدل على ذلك أن الخطاب بالتكون لا يرد

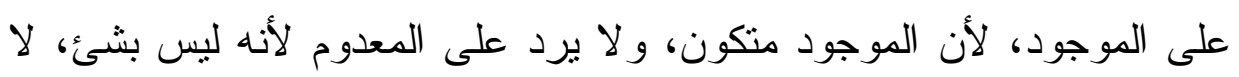

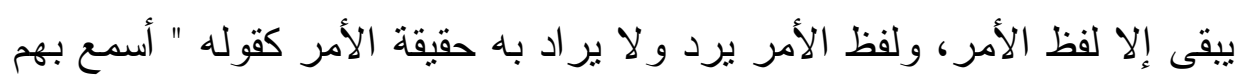

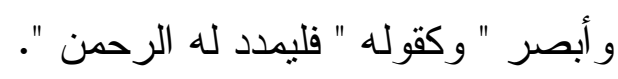
والوجه الثاني: أن جو اب الأمر لابد أن يخالف الأمر إما في الفعل أو في الفاعل أو فيهما، فمثال ذلك قولك: اذهب ينفعك زيد، فالفعل و الفاعل في الجو اب غيرهما في الأمر، وتقول: اذهب يذهب زيد، فالفعلان متفقان و الفاعلان

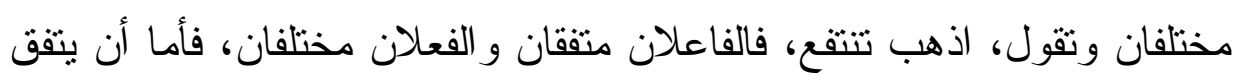
الفعلان و الفاعلان فغير جائز كقولك: اذهب تذهب، و العلة فيه أن الثئ لا يكون

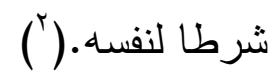

\section{نْفْيد ما نْمْوم من طمون:}

أولا: من جهة السند: قال الإمام أبو حيان الأندلسى: "وحكى ابن عطية، عن فون أحمد بن موسى، في قراءة ابن عامر : أنها لحن، وهذا قول خطأ، لأن هذه الأن الأنئ القر اعة في السبعة، فهي قر اءة متو اترة، ثم هي بعد قر اعة ابن عامر، وهو رجل ولن

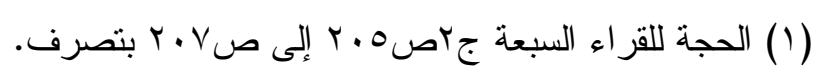

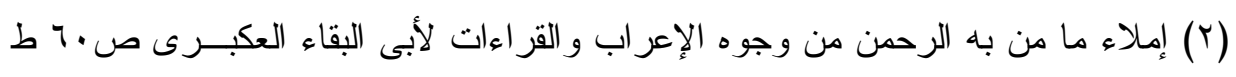

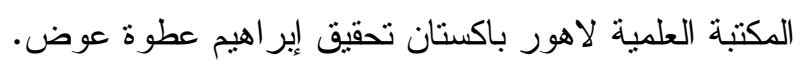


عربي، لم يكن ليلحن. وقر اءة الكسائي في بعض المو اضع، وهو إمام الكوفيين

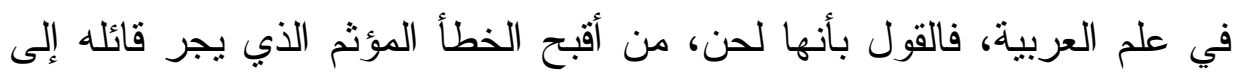

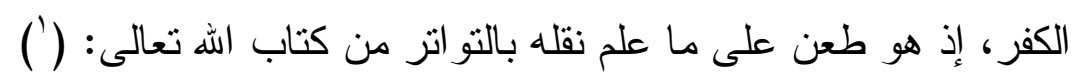
ثانيا من جهة العربية: هذا الأى أنكره الزجاج والفارسى ومن نحى نحوهما أجازه الكوفيون

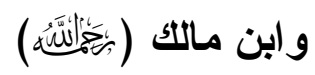
قال ابن مالك:

وبعد إنما وقول كملا ** قد ينصب الفعل الأى فاء تلا(ب)

يقول ابن مالكك فى شرح هذا النظم: وكذلك أجروا -الكوفيون- الحصر

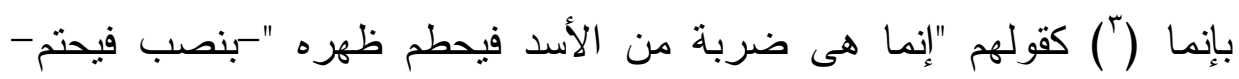

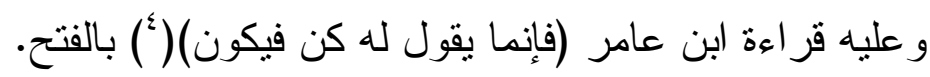

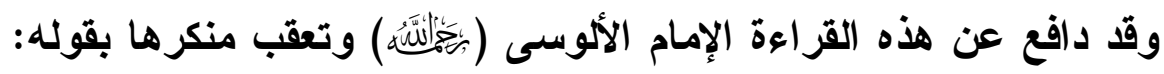

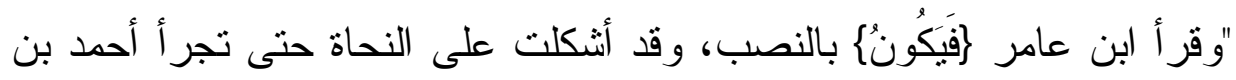
موسى فحكم بخطئها وهو سوء أدب بل من أقبح الخطأ ووجهها أن تكون حينئذ جو اب الأمر حملاً على صورة اللفظ وإن كان معناه الخبر إذ ليس معناه تعليق

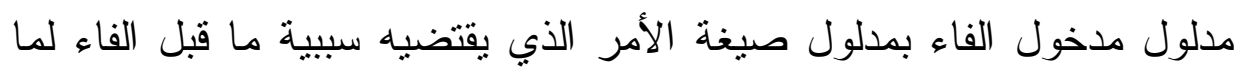
بعدها اللازمة لجواب الأمر بالفاء إذ لا معنى لقولنا ليكن منك كون فكون،

$$
\text { (1) (1) تفسير البحر المحيط لأبى حيان جاصبrه. }
$$

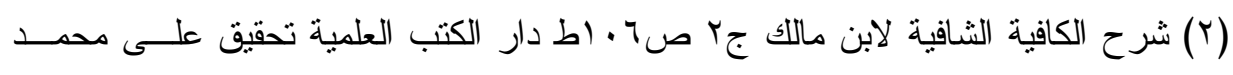

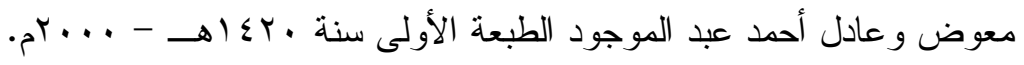

$$
\begin{aligned}
& \text { (r) أى أجرى الكوفيون الحصر بإنما مجرى النفى فى إيلائه جو ابا منصوبا. }
\end{aligned}
$$

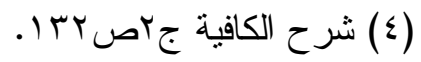


وقيل: الداعي إلى الحمل على اللفظ أن الأمر ليس حقيقياً فلا ينصب جو ابه و إن من شرط ذلك أن ينعقد منهما شرط وجزاء نحو ائتتي فأكرمك إذ تقديره إن تأتتي أكرمك، وهنا لا يصح إن يكن يكن وإلا لزم كون الثيء سبياً لنفسه،

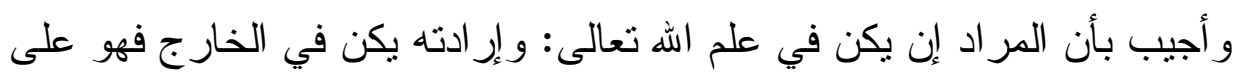
حد 》امن كانت هجرته إلى الله ورسوله فهرته إلى الله ورسولهي وبأن كون الأمر غير الحقيقي لا ينصب في جوابه ممنوع فإن كان بلفظ فظاهر ولكنه مجاز عن سرعة التكوين و إن لم يعتبر فهو مجاز عن إر ادة سرعته فيؤول إلى هـ أن ير اد سرعة وجود شيء يوجد في الحال فلا محذور للتغاير الظاهر و لا

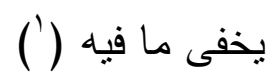

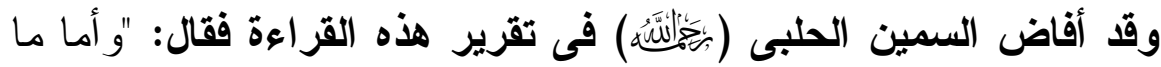
انفرد به ابن عامر فى هذه المواضع الأربعة( () فقد اضطرب كلام الناس فيها وهى لعمرى تحتاج إلى فضل نظر وتأمل ولذلك تجر أ بعض الناس على هذا الإمام الكبير - فذكر الطعون السابقة- ثم قال: و أكثر ما أجابو ا بأن هذا مما روعى فيه ظاهر اللفظ من غير نظر للمعنى، يريدون أنه قد وجد فى اللفظ صورة أمر فنصبنا فى جوابه بالفاء وأما إذا نظرنا إلى جانب المعنى فإن ذلك لا يصح لوجهين:أحدهما: أن هذا وإن كان بان

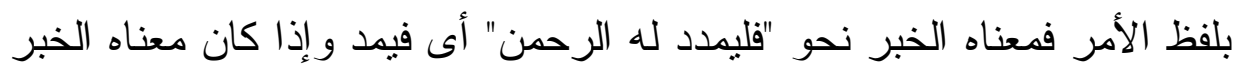
لم ينتصب فى جو ابه بالفاء إلا فى ضرورة كقوله:

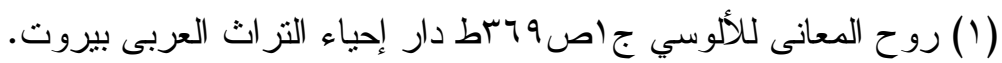

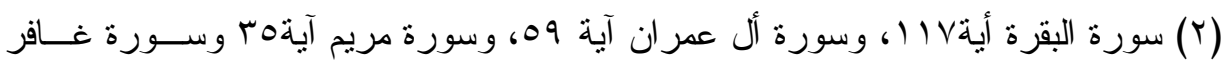

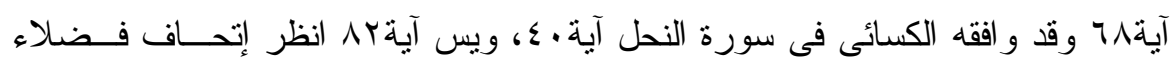

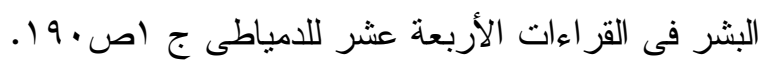




\section{إقامة الحجة على مدعى تلحين القراء السبعل}

سأترك منزلي لبني تميمٍ ** و وألحق بالحجاز فأستريحا(')

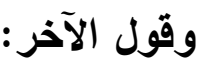

لنا هضبةٌ لا ينزل الذل وسطها * ** ويأوي إليها المستجير فيعصما(ب)

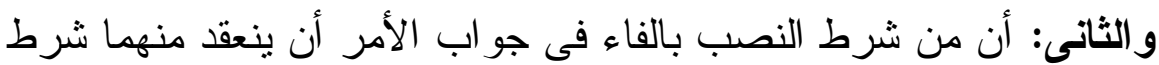

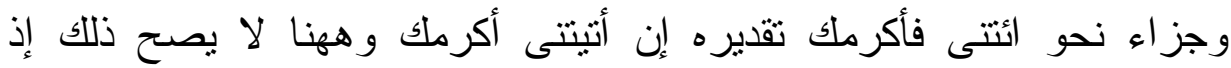

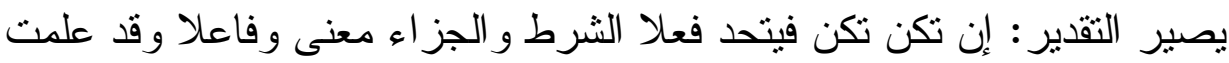

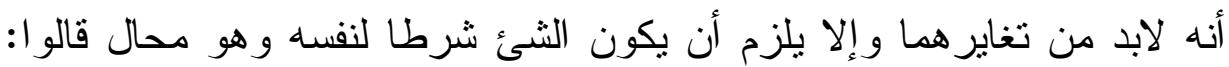

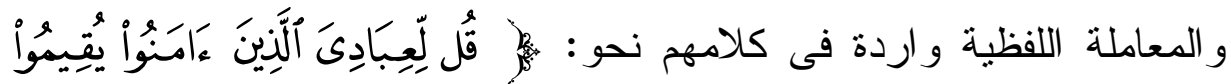

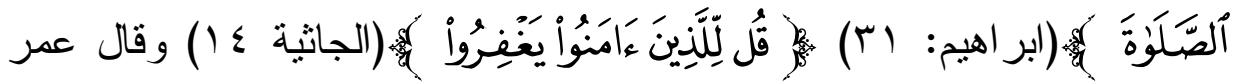

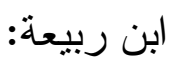

فقلت لجناد خذ السيف و اثشتمل ** عليه برفق وارتقب الثمس تغرب و أسرج لى الدهماء و اذهب بممطرى *** ولا يعلمن خلق من الناس مذهبى(")

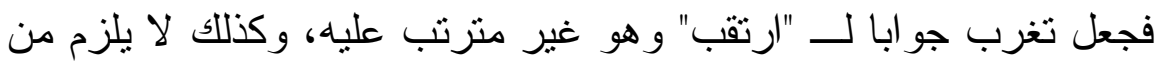

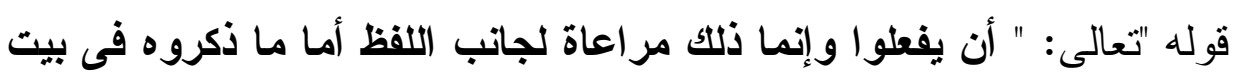

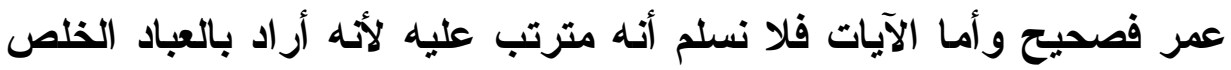
ولذلك أضافهم إليه، أو تقول إن الجزم على حذف لام الأمر وسيأتى تحقيقه

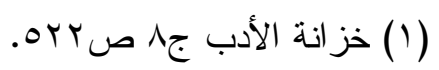

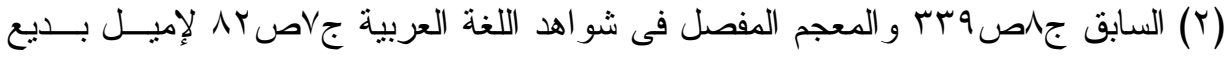

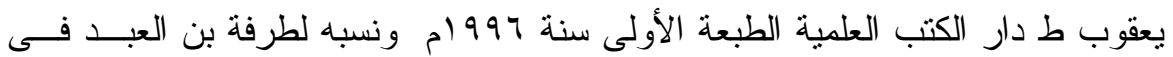

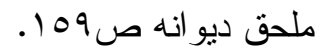

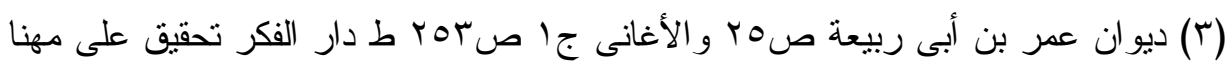

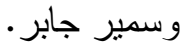


فى موضعه وقال الثيخ جمال الدين ابن مالكك: إن " أن" الناصبة قد تضمر بعد الحصر بإنما اختيارا وحكاه عن بعض الكوفين قال وحكوا عن العرب "

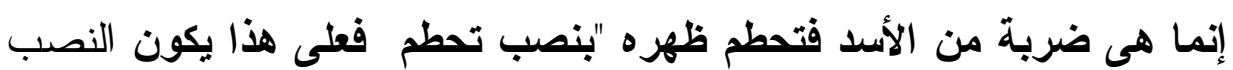
فى فر اءة ابن عامر على ذلك (') وخلاصة ما تقدم أن قراعة ابن عامر متواترة سندا وموافقة للعربية فقد أجازها نحاة الكوفة وابن مالك فقد أجروا الحصر بإنما مجرى النفى فى أن يليه جواب منصوب بأن المضمرة وليس قول البصريين بالحجة على قول الكوفيين خاصة وقد استدلوا على ذلك بكلام العرب نظمه ونثره وعلى ذلك فلا وجه لما ذهب إليه الطاعنون وتبين سلامة قراءة ابن عامر من القدح

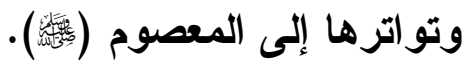

\section{|لقر|هة|لسادسة:}

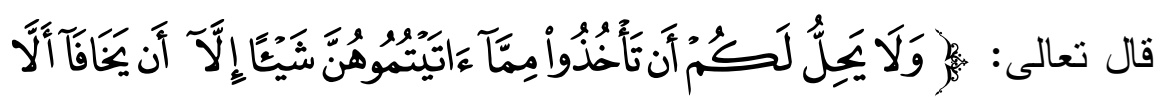

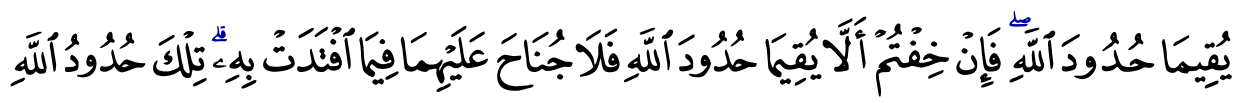

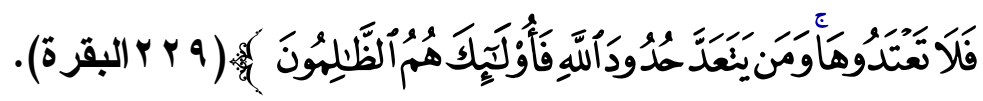

قر أ حمزة و أبو جعفر ويعقوب و الأعمش و الحسن ومجاهد "إلا أن يخافا" على بناء الفعل للمفعول وهو اختيار أبى عبيد(') وقد طعن فى هذه القر اءة أبو ولو جعفر النحاس من جهة الإعر اب و اللفظ و المعنى و إليك تفصيل ذلك:

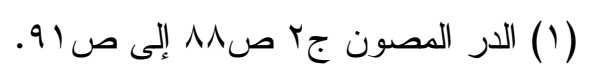

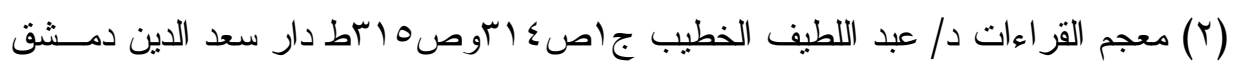

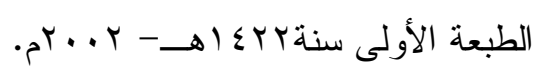

